\title{
各種石炭からの活性炭の製造 ——石炭の直接賦活および乾式・湿式炭化後の賦活の効果—
}

\author{
（1979 年 6 月 4 日受理）
}

笠岡成光・阪田鿆作・椎野铖・足立芳郎・森下仁志*

石炭から高性能活性炭を高収率で製造する至適条件の見直し，ならびに確立の資とするために，固定 炭素分 (F.C.)/揮発分 (V.M.) の比が 1.8 7.7で，粘結性の大きく異なる 8 種の石炭試料（平均粒径 $1.0 \mathrm{~mm})$ について，石炭の直接賦活や，㡷化条件が後続の賦活にどのような效果を与えるかを，活性 炭収率 $Y(\mathrm{~g}$ (生成活性炭 $) / \mathrm{g}$ (原料石炭) ) と表面積 $S_{\mathrm{g}}\left(\mathrm{m}^{2} / \mathrm{g}\right.$ (生成活性炭))の向上主眼を拈いて, $S_{\mathrm{p}}=$ $Y S_{\mathrm{g}}\left(\mathrm{m}^{2}\right.$ (生成活性炭) $/ \mathrm{g}$ (原料石炭) ) あるいは $S_{\mathrm{c}}=Y S_{\mathrm{g}} / \alpha$ ( $\mathrm{m}^{2}$ (生成活性炭) $/ \mathrm{g}$ (原料石炭中の F.C. +灰 分)）を評価の基準にして検討した。すおなち，空気， $\mathrm{HCl}(5 \%)$-空気，あるいは $\mathrm{CO}_{2}$ 中における乾 式炭化 $\left(300 \sim 400^{\circ} \mathrm{C}\right)$ および熱湿硫酸による湿式炭化 $\left(150^{\circ} \mathrm{C}\right)$ と，後続のスチーム， $\mathrm{CO}_{2}, \mathrm{H}_{2} \mathrm{O}-\mathrm{CO}_{2}$ 混 合ガス， $\mathrm{N}_{2}$ による賦活 $\left(700 \sim 1000^{\circ} \mathrm{C}\right.$ ，主として $\left.900^{\circ} \mathrm{C}\right)$ などを組み合わせた 2 段処理法と石炭の直接 賦活法の比較を行ない,つきのような結果・知見を得た。

（1） 2 段迌理法では炭化の方法・条件が，また直接賦活法では原料石炭の炭化度や性状が賦活時の 練孔開発工程 $\left(S_{\mathrm{p}}\right.$ 対 $Y$ あるいは $S_{\mathrm{o}}$ 対 $\left.Y / \alpha\right)$ に大きく影響し, 生成活性炭のX線的な炭素質構造も賦 活前の炭化物あるいは石炭の状態により，注決定される。

（2）炭化度の低い石炭(F.C./V.M.<3 あるいはＦ.C.+灰分 $<75 \%$ ）では，HCl-空氛混合ガスに よる乾式炭化・賦活の 2 段処理法あるいは直接賦活法が, またこれより炭化度の高い石炭では, 湿式灰 化・賦活の 2 段処理法が， $Y, S_{\mathrm{g}}$ ともに大きい製造法として適してお゙， $Y=40 \sim 70 \%$ で， $S_{\mathrm{g}}=500 \sim$ $1000 \mathrm{~m}^{2} / \mathrm{g}$ の活性炭が得られる。

（3）スチーム $\left(10 \% \mathrm{H}_{2} \mathrm{O}-\mathrm{N}_{2}\right)$ 賦活は，低温度 $\left(700 \sim 800^{\circ} \mathrm{C}\right)$ ・長時間よりは，高温 $\left(900^{\circ} \mathrm{C}\right)$ ・短時間 (1 時間程度)の処理が望ましい。また，賦活前に炭化物を不活性がス $\left(\mathrm{N}_{2}\right)$ 中であらかじめ高温 $\left(900^{\circ} \mathrm{C}\right)$ で熱処理しておくと，部分的なハードカーボン化が起こり，Yを向上させる。

（4）生成活性炭の液相 $\left(\mathrm{I}_{2}\right.$ (分子状), $\mathrm{UO}_{2}{ }^{2+}, \mathrm{PO}_{4}{ }^{3-}$ ) での吸着量 $q$ は原料石炭や製造法にあまり関係 なく, $q\left(\mathrm{mg}\left(\mathrm{I}_{2}\right) / \mathrm{g}\right.$ (生成活性炭) $)=1.20 S_{\mathrm{g}}, q(\mathrm{mg}(\mathrm{U}) / \mathrm{g}$ (生成活性炭) $)=0.18 S_{\mathrm{g}}, q\left(\mathrm{mg}\left(\mathrm{PO}_{4}^{\mathrm{s}}\right) / \mathrm{g}(\right.$ (生 成活性炭 $)=0.012 S_{\mathrm{g}}$ で，それぞれ表わされ，既報のボリ塩化ビニルやボリカルボナートからつくった 活性炭とくらべると, $\mathrm{PO}_{4}{ }^{3-} か ゙ 2$ 倍の吸着量を示す以外は, 吸着能はまったく同じで, また市販の高級 ヤシ殼系活性炭とも遜色はみられない。

（5）触媒能(硫酸酸性溶液中の $\mathrm{Fe}^{2+}$ の $\mathrm{Fe}^{3+}$ への空気酸化能）は，プラスチックからの活性炭では ほとんど認められないのに対して, 石炭からの本活性炭では, 市販の高級ヤシ殸系活性炭と同程度であ る。

\section{1 楮 专}

㷋来, 活性炭のほとんとはヤシ殻、石岸などから、これらを比 敬的低温で熱処理することによって，縮合環化反応を释て無定形 岑案にいたらしめる炭化の工程と,こらして得られた孷化物を， $800^{\circ} \mathrm{C}$ 付近以上で, 水蒸気, 二酸化能素などの弱酸化性军团気流 中で処理し，炭化物に残存する炭化水素化合物を熱分解・ガス化 することによって細孔を形成させ，かつ活性な表面状態沉改質さ せる翢活の工程の二段階て製造されている。

$*$ 冏山大学工学部合成化学教室, 700 埇山咘津島中
周知のよらに, 近年, 活性炭俚有害・悪臭ガス・蒸気の吸着除 去や産業排水の高度処理なぞにその利用が急增し，活性でから廉 佂な大量製造方式が原料資源の探索々併わせて強く要望されてお り，著者らも，さきにブラスチック廃率物の処理を活性庆製造一 の资源化と兼机て，ボリ塩化ビニル(PVC)やボリカルボナート榯 脂 $(\mathrm{PC})$ なと数種のブラスチックを原料として活性炭の製造を試 み，之の結果，熱分解特性 (分解開始温度・分解速度曲線の様相)

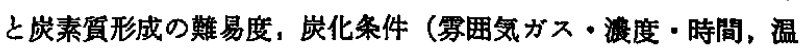
度 (界温・定温))の㒃活への影警, 岸化・賦活の進行にともな5 活性宸収率 $Y\left(\mathrm{~m}^{2}\right.$ (生成活性炭 $) / \mathrm{g}$ (原料) ) 之表面積 $S_{\mathrm{g}}\left(\mathrm{m}^{2} / \mathrm{g}\right.$ (生 
Table 1 Proximate analysis and properties of raw coal samples for preparation of activated carbon found in literatures

\begin{tabular}{|c|c|c|c|c|c|c|c|c|}
\hline \multirow{2}{*}{ Coal } & \multirow{2}{*}{ Coking } & \multirow{2}{*}{$\begin{array}{l}\text { Original } \\
\text { country }\end{array}$} & \multicolumn{3}{|c|}{ Proximate analysis (\%) } & \multirow{2}{*}{$\begin{array}{c}\text { Ratio of } \\
\text { F.C./V.M. } \\
(-)\end{array}$} & \multirow{2}{*}{$\begin{array}{l}\alpha^{c)} \\
(\%)\end{array}$} & \multirow{2}{*}{$\begin{array}{l}\text { Literature } \\
\text { cited }\end{array}$} \\
\hline & & & Ash & V. M. ${ }^{a)}$ & F.C. ${ }^{b}$ & & & \\
\hline Jyobankushigata & - & Japan & 11.8 & 49.9 & 38.2 & 0.766 & 50.0 & 9 \\
\hline Kashima & None & Japan & 8. 2 & 50.8 & 40.9 & 0.805 . & 49.1 & 6 \\
\hline Taiheiyo & None & Japan & 10.8 & 48.3 & 40.9 & $0.846^{\circ}$ & 51.7 & 6 \\
\hline Brawn coal & None & $?$ & 11.1 & 47.6 & 41.3 & 0.868 & 52.4 & 3 \\
\hline Yallourn & None & Australia & 1.7 & 52.6 & 45.7 & 0.869 & 47.4 & 6 \\
\hline Taiheiyo & None & Japan & 8. 34 & 48.16 & 43.50 & 0.903 & 51.84 & 7 \\
\hline Yallourn & None & Australia & 1.3 & 51.4 & 47.3 & 0.920 & 48. 6 & 9 \\
\hline Horonai & Weak & Japan & 5.64 & 47.94 & 46.73 & 0.975 & 52.37 & 7 \\
\hline Miike No. 68 & - & Japan & 12.4 & 40.7 & 43.9 & 1.08 & 56.3 & 10 \\
\hline Miike & - & Japan & 7.9 & 43.3 & 48.8 & 1.13 & 56.7 & $\mathbf{5}$ \\
\hline $\begin{array}{l}\text { Sunagawa, } \\
\text { upper seam No. } 8\end{array}$ & Weak & Japan & 6.91 & 43.55 & 49.54 & 1. 138 & 56.45 & 7 \\
\hline Akahira & Weak & Japan & 6.1 & 43.0 & 50.9 & 1.19 & 57.0 & 4 \\
\hline Big ben & Weak & Australia & 10.2 & 34.6 & 55.2 & 1.59 & 65.4 & 8 \\
\hline Moura & Moderate & Australia & 9.3 & 25.4 & 65.3 & 2.57 & 74.6 & 8 \\
\hline Black Water & Moderate & Australia & 6.8 & 25.1 & 68.1 & 2.71 & 74.9 & 8 \\
\hline Ohnishi & $\longrightarrow$ & Japan & 6.5 & 6.8 & 86.7 & 12.8 & 93.2 & 10 \\
\hline
\end{tabular}

成活住炭))の成係などを明らかにし，とくに炭化のさいの昇盜速 度, 算温上限温度かよび上限温度における保持時間が原料ブラス チックの分解開始温度や溶融性などの特性と適合しないような场

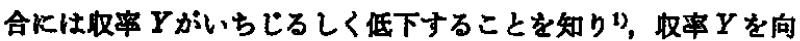
上させるためには，たとえば PVCでは熱分解により発生する $\mathrm{HCl}$ ガスを利用して，少贯の $\mathrm{Cu}(0.1 \%$ 程度) を添加した状態 で空気あるいは HCl-空父混合ガスによる酸化塩票化を行なわせ た英化処理が，また，たとえば PCのように，原料中の炭素含有 率 $\alpha_{c}(75.6 \%)$ の大きいるのでは, 㒃活処理の前の疢化物の不活性 ガス中で商温下での繁处理が有効であることなどる)を報告した。

さて，石宸を原料とする活性些の製造に関しては，古くから数 多くの報告帛) -12)があり，賦活工程（賦活帆率 $y_{\mathrm{a}}$ (g(生成活性炭)!

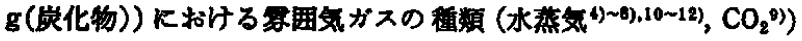

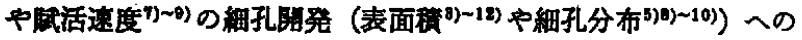

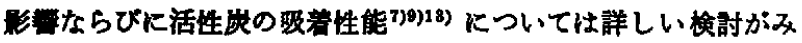

1）笠岡成光，板田祐作，三村瞩幸，山戸秀夫，日化，1976， 1631.

2）笠岡成光, 阪田咗作, 山戸答夫, 西山 岳, 化学工学協会 第 43 年会袢演要旨集 $(1978)$ : 日化，投稿中.

3) 柳井 弘, 化学工学, 26, 518(1962).

4) 北川 浩, 工化, 74, 1383(1971).

5) 北川 浩, 工化, 74, 1981(1971).

6) 北川 浩, 日化, 1972, 1140 .

7）石棆一二，野田息男，三井茂夫，然協誌，52，336(1973).

8）北州浩, 日化, 1973, 2356.

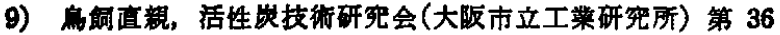
回請演会要旨 (1975).

10) F. Watanabe, Y. Yamada, M. Hasatani, S. Sugiyama, J. Chem. Eng. Jpn., 9, 314(1976)

11）田崎米四郎, 河端淳一, 三井茂夫, 然協誌, 57, 781(1978).

12) K. Hashimoto, K. Miura, F. Yoshikawa, I. Imai, Ind. Eng. Chem., Process Des. Dev., 18, 72(1979).

13）北川 沿, 日化, 1975, 1631 .
られるが，その前段階の能化工程（岸化収率 $y_{\mathrm{c}}(\mathrm{g}$ (炭化物)/g(原 料)，すなわち炭化物の生成履整る含めた原料石炭基準の活性能 収率 $\boldsymbol{Y}\left(=y_{0} \times y_{\mathrm{a}}\right)$ を用いて製造条件とくに炭化法との関連性を 論じたものははとんど見あたらない5)。これは石炭中の水分や揮 発分の愘合が種類や受入条件などによって大きく変動し、ブラス チックを原料とする場合とくらべると，原料重量の採り方の基準 （たとえば彰煤度）を明確に決めがたいことによるすのと思われ る。

また，石炭の炭化度や粘結性は，細孔開発の嚾易度ばかりでな く，生成活性炭の造粒珄や強度に大きく影響するがけ5)9)，このよ らな石岸の特性との関連に対しても系統的に検討された報告は見 あたらず，既往の報告で用いられてきた石炭（表 1) は然料比 （固定炭菜分の揮発分に対する比）が $0.8 \sim 1.2$ 程度と，比校的低 く，かつ粘結性のそしい,いわ伸る褐能が多い。

本研究では，石炭から活性炭の製造法の見直しの一つとして， 報告例の少ない，然料比が 1.8 7.7 と大きく, かつ粘結性のか なり異なる 8 種の石岸を用いて，さきに著者らがブラスチックを 原料とする活性炭の製造において，提出した概念》を採り入れ，原 料石炭の単位筫量あたり, あるい瑔料石炭中の固定炭素と灰分 を加えた単位筫量あたりの表面程 $S_{\mathrm{p}}\left(=Y S_{\mathrm{g}} ; \mathrm{m}^{2}\right.$ (生成活性炭)/ $\mathbf{g}$ (原料石炭)) あるい忙 $S_{\mathrm{c}}\left(=Y S_{\mathrm{g}} / \alpha ; \mathrm{m}^{2}\right.$ (生成活性炭) $/ \mathrm{g}$ (原料石 炭中の固定炭素十灰分)) を指摽として, 高性能活性炭を高收率 で得るための炭化処理と䟼活処理の場合の塄囲気ガス・温度・時 間などの条件について，基礎的な検討を試み，とくに HCl-空忽 混合ガスによる乾式炭化と浦野らかの石炭を原料とした陽イオン 交煥吸着成の製造で試みられた浱硫酸処理による湿式炭化による 孷化物を，それぞれスチーム賦活した 2 段処理による方法と，岸 化工程をまったく省いた石炭の植接スチーム賦活の一段边理によ る方法の比較を行ない，有意な結果・知見を得たので報告する。

14）浦野絠平，清浦雷作，工化，74，247(1971). 
Table 2 Properties of coal samples ${ }^{a)}$

\begin{tabular}{|c|c|c|c|c|c|c|c|c|c|c|c|}
\hline \multirow{2}{*}{ Coal } & \multirow{2}{*}{$\begin{array}{l}\text { Original } \\
\text { country }\end{array}$} & \multirow{2}{*}{ Coking } & \multicolumn{3}{|c|}{ Proximate analysis ${ }^{b}(\%)$} & \multirow{2}{*}{$\begin{array}{l}\text { Ratio of } \\
\text { F.C./V.M. }\end{array}$} & \multirow{2}{*}{$\begin{array}{l}\alpha^{d)} \\
(\%)\end{array}$} & \multirow{2}{*}{$\begin{array}{c}S_{g} \\
\left(\mathrm{~m}^{2} / \mathrm{g}\right)\end{array}$} & \multirow{2}{*}{$\begin{array}{c}t_{\mathrm{d}}^{(e)} \\
\left({ }^{\circ} \mathrm{C}\right)\end{array}$} & \multirow{2}{*}{$\left(\begin{array}{c}\left.t_{8}^{f}\right) \\
\left({ }^{\circ} \mathrm{C}\right)\end{array}\right.$} & \multirow{2}{*}{$y_{c}^{n}$} \\
\hline & & & Ash & V.M. ${ }^{o)}$ & F. C. ${ }^{c)}$ & & & & & & \\
\hline A : Collie & Australia & None & 6.2 & 34.1 & 59.8 & 1.76 & 65.9 & 2.5 & 280 & +50 & 1.260 \\
\hline B : Kellerman & USA & Strong & 2.4 & 34.9 & 62.7 & 1.80 & 65.2 & 0.2 & 350 & +10 & 1.179 \\
\hline C : Blair Athol & Australia & None & 7.8 & 27.4 & 64.8 & 2.36 & 72.6 & 33.3 & 350 & +25 & 1. 105 \\
\hline D : South Black Water & Australia & Moderate & 6.5 & 26.8 & 66.6 & 2.48 & 73.2 & 1.1 & 370 & $\sim 0 \sim$ & 1.209 \\
\hline E : Pittstone & USA & Strong & 3.7 & 20.5 & 75.8 & 3.67 & 79.5 & 0.2 & 380 & -20 & 1.351 \\
\hline F : Keystone & USA & Moderate & 6.3 & 16.9 & 76. 8 & 4. 55 & 83.1 & 0.2 & 400 & -25 & 1.358 \\
\hline G : Kuznetsk & USSR & Moderate & 8.7 & 14.0 & 77.4 & 5.55 & 86.1 & 0.3 & 400 & $\sim 0 \sim$ & 1.318 \\
\hline $\mathrm{H}$ : Uonuki & Japan & None & 8.4 & 10.6 & 81.0 & 7.67 & 89.4 & 0.3 & 400 & -50 & 1.085 \\
\hline
\end{tabular}

a) Dried $\left(110^{\circ} \mathrm{C}\right.$ for $\left.1 \mathrm{hr}\right)$ weight basis.

b) Analysis based on JIS M-8812.

c) V.M.: Volatile matter, F.C.: Fixed carbon.

d) Fractional weight of the sum of fixed carbon and ash.

e) Initiation temperature of decomposition (weight decrease) in nitrogen gas.

f) Change of initiation temperature of gasification by adding $\mathrm{HCl}(5 \%)$ to air.

g) Yield of char carbonized by treating coal $(20 \mathrm{~g})$ with conc. $\mathrm{H}_{2} \mathrm{SO}_{4}(200 \mathrm{ml})$ at $150^{\circ} \mathrm{C}$ for $1 \mathrm{hr}$

\section{2 石炭站料}

本実跧で用いた 8 種の原料石炭 $(A \sim H)$ と, これらの JIS M8812 に準观した工業分析值（扊分，揮発分 V.M., 固定炭素分 F.C.)，炭化度の指標として F.C./V.M. 比（然料比），また活 性炭收率 $Y$ の目安としての F.C. と灰分の含有率の和 $\alpha$, 表面栍 などを総括して表 2 に示した。すなわち，本石炭試料は，表 1 に 示した既往の報告の多くにみられる褐岸(F.C./V.M.: 0.77〜1.19 ; F.C.: 38.2〜50. 9\%， $\alpha=47.4 \sim 57.0 \%)$ とくらべると，才べ て孷化度が高い(F.C./V.M.: 1.76 7.67; F.C.: 59.8 81.0\%, $\alpha: 65.9 \sim 89.4 \%$ ) るのである。また，表 2 中の $t_{\mathrm{d}}$ は，灰化処 理温度を決める目安とするために行なった $\mathrm{N}_{2}$ 気流中での昇温時 $\left(4^{\circ} \mathrm{C} / \mathrm{min}\right)$ の揮発による重量減少開始温度で $280^{\circ} \mathrm{C}$ 付近から 400 “付近まで能化度の大きいものほど㐫くなっている(空気気流中 で界温した场合も汪とんど変わらない)。

さて，原料石岩のX線回折図を図 1 に示したが，岸化度が高く なるにしたがって，黑雓の (002) 面に相当する幅広いビークが回 折角 $2 \theta\left(\mathrm{Cu} K_{a}\right)$ で $20^{\circ}$ 付近から $26^{\circ}$ 付近まで移動し, 層面間

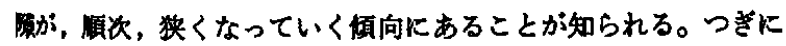
O'Gorman ら ${ }^{15)}$ の報告を参考にしてX 線回折で同定された石岑 中に含まれる鉱物成分について，石炭を空氛中， $750^{\circ} \mathrm{C}$ 付近で約 1 時間, 然雄させて得た灰分 (HTA) の結果とも併わせて表 3 に 示した。

石炭 $\mathrm{A} \sim \mathrm{F}$ で同定された kaolinite は $550^{\circ} \mathrm{C}$ 付近の䓡姏理で

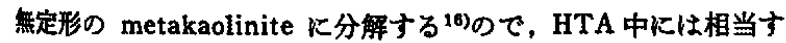
るピーク仕認められなくなる。同じ粘土鉱物の illite は kaolinite より恃炭化度の高い石刿 $(\mathrm{D} \sim \mathrm{H})$ に多くみられる㑯向にあ った。 quartz と anhydrite $\left(\mathrm{CaSO}_{4}\right)$ は, すべての石炭の HTA 中に, またG以外の石炭の HTA 中に hematite $\left(\alpha-\mathrm{Fe}_{2} \mathrm{O}_{3}\right)$ が同 定された。この HTA 中の anhydrite は, 石炭Hの揚合のよう Kgypsum(CaSO $\left.{ }_{4} \cdot 2 \mathrm{H}_{2} \mathrm{O}\right)$ の脱水によるむのむあるが, 一般に (石岇 E，G，H では明らかに）石炭中の有機系あるいは無機系

\footnotetext{
15) J. V. O'Gorman, P. L. Walker, Jr., U. S. Dept. Interior OCR Rand D Report, No. 61, Interim Rept. 2(1972).

16) R.S. Mitchell, H. J. Gluskoter, Fuel, 55, 90(1976).
}

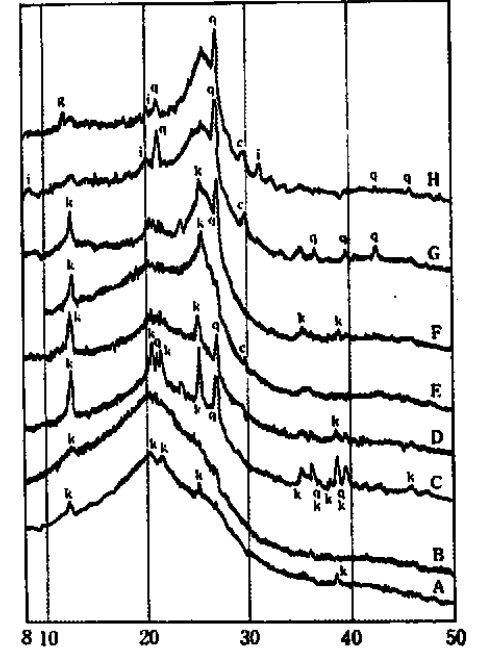

Diffraction angle, $2 \theta\left(\mathrm{Cu} K_{a}\right)$ (degree)

Fig. $1 \mathrm{X}$-ray diffractograms of raw coal ( $A$ to $H$ ) shown in Table 2

c: Calcite, g: Gypsum, i : Illite, k: Kaolinite, q: Quartz

の硫黄化合物 (たとえば pyrite $\left(\mathrm{FeS}_{2}\right)$ p pyrrhotite(FeS)) か ら生成した $\mathrm{SO}_{x}$ の石质中の $\mathrm{Ca}$ 化合物 (たとえば, calcite(Ca. $\left.\mathrm{CO}_{3}\right)$ ) との反応によるるのが會まれている。ともかく，表 2 に示

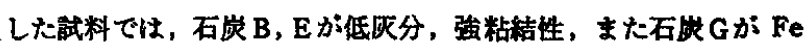
分を注とんど含まない高灰分であることが特改である。

\section{3 实験方法}

\section{1 炭化およひ眗活}

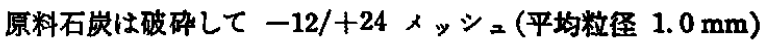
にふるいわけしたものを, $110^{\circ} \mathrm{C}$ で空気流中(一部, $\mathrm{N}_{2}$ 気流中), 1 時間，乾嬠し、この場合の重覀を基準として実験に用いた。 乾式炭化処理は，空気， $\mathrm{CO}_{2}$ および $\mathrm{HCl}(5 \%)$-空気湦合ガス 流中で行ない，用いた装疄と手法は既報1)22のブラスチック原料 の埸合と同じ，Kjeldah1 型フラスョ(内容 $1 l$ )とマントルヒータ 
Table 3 Mineral matters in raw coal and its HTA $^{a}$ detected by $\mathrm{X}$-ray diffraction analysis ${ }^{(b)}$

\begin{tabular}{|c|c|c|c|c|c|c|c|c|c|}
\hline \multirow{2}{*}{\multicolumn{3}{|c|}{ Sample }} & \multicolumn{7}{|c|}{ Mineral matters ${ }^{c)}$} \\
\hline & & & $q$ & $\mathbf{k}$ & $\mathrm{i}$ & c & $\mathrm{g}$ & a & h \\
\hline A & Collie & $\begin{array}{l}\text { Coal } \\
\text { HTA }\end{array}$ & $\overline{\mathrm{W}}$ & $\underline{w}$ & $=$ & $=$ & $\bar{z}$ & $\overline{\mathrm{w}}$ & $\bar{M}$ \\
\hline B & Kellerman & $\begin{array}{l}\text { Coal } \\
\text { HTA }\end{array}$ & $\begin{array}{l}\mathrm{VW} \\
\mathrm{W}\end{array}$ & $\underline{w}$ & $\overline{\mathrm{w}}$ & $=$ & $=$ & $\overrightarrow{\mathrm{M}}$ & $\overline{\mathrm{S}}$ \\
\hline C & Blair Athol & $\begin{array}{l}\text { Coal } \\
\text { HTA }\end{array}$ & $\begin{array}{l}S \\
S\end{array}$ & $\underline{s}$ & $=$ & $=$ & $=$ & $\bar{W}$ & $\overline{\mathrm{W}}$ \\
\hline D & $\begin{array}{l}\text { South } \\
\text { Black Water }\end{array}$ & $\begin{array}{l}\text { Coal } \\
\text { HTA }\end{array}$ & $\begin{array}{l}\mathrm{M} \\
\mathrm{S}\end{array}$ & $\underline{M}$ & $\bar{M}$ & $=$ & $\overline{-}$ & $\overline{\mathrm{W}}$ & $\bar{M}$ \\
\hline $\mathbf{E}$ & Pittstone & $\begin{array}{l}\text { Coal } \\
\text { HTA }\end{array}$ & $\begin{array}{l}\mathrm{VW} \\
\mathrm{W}\end{array}$ & $\underline{M}$ & $\overline{\mathrm{w}}$ & vW & $=$ & $\overline{\mathrm{M}}$ & $\bar{M}$ \\
\hline F & Keystone & $\begin{array}{l}\text { Coal } \\
\text { HTA }\end{array}$ & $\stackrel{\mathrm{M}}{\mathrm{W}}$ & $\underline{M}$ & $\bar{M}$ & $\overline{-}$ & $=$ & $\bar{M}$ & $\overline{\mathrm{W}}$ \\
\hline G & Kuznetsk & $\begin{array}{l}\text { Coal } \\
\text { HTA }\end{array}$ & $\begin{array}{l}\text { S } \\
\text { vS }\end{array}$ & $=$ & $\begin{array}{l}\text { W } \\
\text { vS }\end{array}$ & $\underline{w}$ & $\overline{-}$ & $\overline{v W}$ & 二 \\
\hline H & Uonuki & $\begin{array}{l}\text { Coal } \\
\text { HTA }\end{array}$ & $\frac{\mathrm{M}}{\mathrm{W}}$ & $=$ & $\stackrel{\mathrm{W}}{\mathrm{M}}$ & $\underline{W}$ & $\underline{w}$ & $\overline{v s}$ & $\vec{s}$ \\
\hline
\end{tabular}

a) HTA : Ash after burning in $\operatorname{air}\left(300 \mathrm{Ncm}^{3} / \mathrm{min}\right)$ at $750^{\circ} \mathrm{C}$ for 1 hour.

b) Relative diffraction intensity.

VS : Very strong, $S$ : Strong, $M$ : Intermediate, $W:$ Weak, VW : Very Weak.

c) q: Quartz, $\mathrm{SiO}_{2}$, k : Kaolinite, $\mathrm{Al}_{2} \mathrm{Si}_{2} \mathrm{O}_{5}(\mathrm{OH})_{4}$, i: lllite, $\mathrm{K}_{(1 \sim 1.5)} \mathrm{Al}_{4}\left(\mathrm{Si}_{(7 \sim 8.5)}\right.$ $\left.\mathrm{Al}_{(1 \sim 1.5} \mathrm{O}_{20}\right)(\mathrm{OH})_{4}$, $\mathrm{c}:$ : Calcite, $\mathrm{CaCO}_{3}, \mathrm{~g}:$ Gypsum, $\mathrm{CaSO}_{4} \cdot 2 \mathrm{H}_{2} \mathrm{O}$, a : Anhydrite, $\mathrm{CaSO}_{4}, \mathrm{~h}$ : Hematite, $\mathrm{Fe}_{2} \mathrm{O}_{3}$.

一(500W) で，原料石岸 $(20 \mathrm{~g})$ の表面に炭化用雾围気ガスがよく 接触するよ5にし，ガスを通しながら $\left(300 \mathrm{Ncm}^{2} / \mathrm{min}\right)$ ，室温か 5 $4^{\circ} \mathrm{C} / \mathrm{min}$ で㫧温し，表 2 亿示した分解開始温度 $\left(t_{\mathrm{d}}\right)$ を参考比 して，上限温度 $t_{s}\left(300 \sim 400^{\circ} \mathrm{C}\right)$ で一定時間（主として 3 時間）

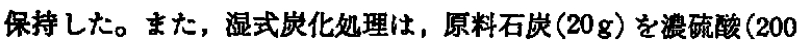
$\mathrm{m} l)$ 中で $150^{\circ} \mathrm{C} て ゙ 1$ 時間かきまぜ処理し，室温まで放冷後，カラ ス沪過器を用いて固液を分麇し，炭化物を十分に水洗し， $110^{\circ} \mathrm{C}$ で 24 時間，乾燥した。

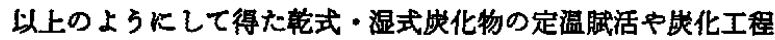
を省いた直接定温䏸活 (以後, 前者を 2 段処理，後者を直接倵活 と呼ぶことにする）は，横型電気沪を用い，石英製反応管（内经 $34 \mathrm{~mm})$ 中に試料(1〜5g) をセットした磁製ボート（長さ 16.4 $\mathrm{mm} \times$ 高さ $11 \mathrm{~mm} \times$ 幅 $20 \mathrm{~mm}$ ) を挿入し，旤活がスの種類・組 成, 温度 $\left(700 \sim 1000^{\circ} \mathrm{C}\right.$, 主として $\left.900^{\circ} \mathrm{C}\right)$ ，時間（0.5 7 時間） を変えて行なった。用いた瞳活ガスは主として $\mathrm{H}_{2} \mathrm{O}$ (主として 10 $\%)-\mathrm{N}_{2}$, その他 $\mathrm{CO}_{2}, \mathrm{H}_{2} \mathrm{O}(10 \%)-\mathrm{CO}_{2}(55 \%)-\mathrm{N}_{2}$ でいずれも 300 $\mathrm{Ncm}^{8} / \mathrm{min}$ で供給した。

なお，笑化物および生成活性嵌（㒃活物）は，すべて，ガスク

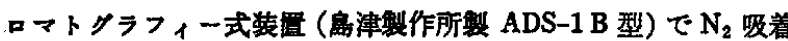

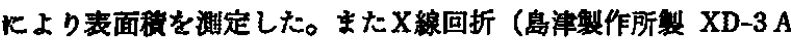
型； $\left.\mathrm{Cu} K_{a}, \mathrm{Ni} フ ィ ル タ ー, 20 \mathrm{~mA}, 40 \mathrm{kV}\right)$ も道宜行なった。 また，取率，表面模值やX線回折図形などについては，適宜，二 重あるいは三重の実呀・測定を行ない，再現性のあることを確か。 めた。

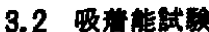

3.2.1 ヨウ来 $\left(\mathrm{I}_{2}\right)$ の吸萧: 生成活性炭 $(30 \mathrm{mg})$ を $\mathrm{I}_{2}$ 水溶液 $\left(5 \times 10^{-8} \mathrm{~mol} / \mathrm{l}\right.$ の $50 \mathrm{ml}$ ) 中に $30^{\circ} \mathrm{C}$ て浸渍し(約 20 時間), $\mathrm{Na}_{2}$. $\mathrm{S}_{2} \mathrm{O}_{3}$ 水溶液比よる滴定法で, 平衡吸着量 $q\left(\mathrm{mg}\left(\mathrm{I}_{2}\right) / \mathrm{g}\right.$ (生成活性 狄)）を求めた。

3.2.2 ウラニル(VI) イオン $\left(\mathrm{UO}_{2}{ }^{2+}\right)$ の䏜米 : 生成活性炭（50 $\mathrm{mg})$ を酛酸ウラニル水溶液 $\left(5 \times 10^{-3} \mathrm{~mol} / l\right.$ の $\left.25 \mathrm{ml}\right)$ 中に, $30^{\circ} \mathrm{C}$ で漫漬し(約 110 時間)，末吸着 $\mathrm{UO}_{2}{ }^{2+}$ を含む試料水溶液を西铅

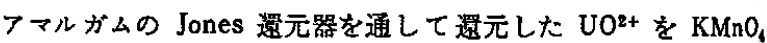
水溶液て滴定し, 平衡吸着量 $q(\mathrm{mg}(\mathrm{U}) / \mathrm{g}$ (生成活性炭)）を求め た。

3.2.3 リン酸イオン $\left(\mathrm{PO}_{4}{ }^{3-}\right)$ の吸着: 生成活性岸 $(50 \mathrm{mg})$ を， リン酸一カリウム水溶液 $\left(5.26 \times 10^{-4} \mathrm{~mol} / l\right.$ の $\left.25 \mathrm{~m} l\right)$ 中に $30^{\circ} \mathrm{C}$ で浸漬し(約 140 時間)，JIS K-102 亿準拠したモリブデン青の発 光による四光光度法（日立製作所製 101 型）により平衡吸着量 $q\left(\mathrm{mg}\left(\mathrm{PO}_{4}{ }^{\mathrm{s}}\right) / \mathrm{g}\right.$ (生成活性能)) を求めた。

\section{3 触媒能試涣}

活性炭浱度 $(\mathrm{g}$ (生成活性岸) $/ \mathrm{g}(\mathrm{Fe}))=3.0$ と乙, $\mathrm{FeSO}_{4}(1 / 200$ $\mathrm{mol})-\mathrm{H}_{2} \mathrm{SO}_{4}(1 / 20 \mathrm{~mol})$ 搌合水溶液 $(50 \mathrm{ml})$ を空気中, $30^{\circ} \mathrm{C}$ て加 己まぜ，10 時間後の溶液を $\mathrm{KMnO}_{4}$ 溶液による滴定法で $\mathrm{Fe}^{2+}$ の $\mathrm{Fe}^{8+}$ への酸化率を求めて触媒能17)評陌した。

\section{4 実験結果ならびに考察}

既報122)のブラスチック原料からの活性炭の製造の場合と同し

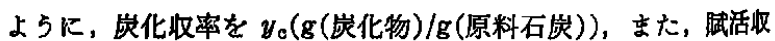
率を $y_{\mathrm{a}}(\mathrm{g}$ (生成活性炭) $/ \mathrm{g}$ (炭化物)) で与兄られるから，生成活 性炭単位筫量あたりの表面掅を $S_{\mathrm{g}}\left(\mathrm{m}^{2} / \mathrm{g}\right.$ (生成活性炭)）とする と，原料石嵅の単位質量あたりの生成活性炭の表面䅡 $S_{\mathrm{p}}$ 注， $S_{\mathrm{p}}$ $=Y S_{\mathrm{g}}$ となり，また原料石炭中の固定炭菜分と灰分の和の単位 質量あたりの生成活性能の表面皘 $S_{\mathrm{c}}$ は $S_{\mathrm{c}}=Y S_{\mathrm{g}} / \alpha$ で表わされ， $S_{\mathrm{p}}$ 対 $Y$ あるいは $S_{\mathrm{c}}$ 対 $Y / \alpha$ の関俰图を求めると，原点を通る それぞれ直線の傾きはそれぞれの $S_{\mathrm{g}}$ に相当し，央験点が，より 右上側にあるもの汪ど， $S_{\mathrm{g}}$ が大きく，かつ収率 $Y$ の大きいこと を示している。

17）笠岡成光，饭田咗作，難波則男，平岡龍三，嶋田 宽，化 学工学論文榃, 3,537 (1977). 


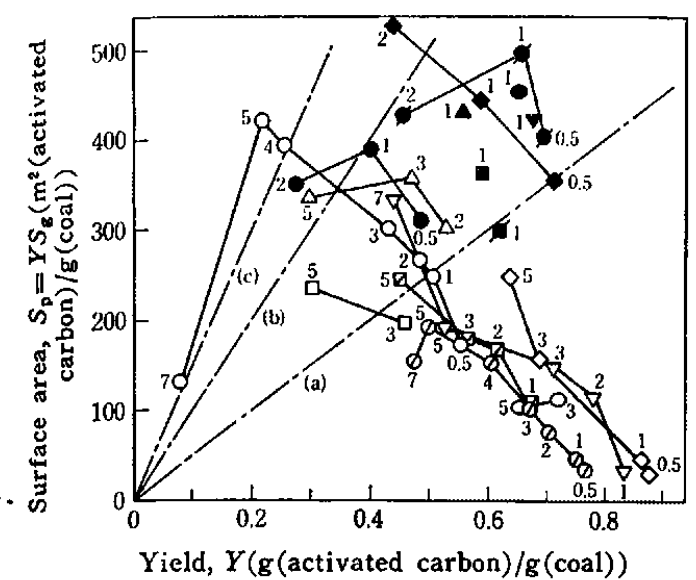

Fig. 2 Direct activation of coal and activation of char carbonized by wet method

Wet method : Treatment with conc. $\mathrm{H}_{2} \mathrm{SO}_{4}$ at $150^{\circ} \mathrm{C}$ for $1 \mathrm{hr}$

Activation : Treatment with $\mathrm{H}_{2} \mathrm{O}(10 \%)-\mathrm{N}_{2}$ at $900^{\circ} \mathrm{C}$ for $0.5 \sim 7 \mathrm{hr}$

Coal-

$\mathrm{O}, \mathrm{A}, \square, \mathbf{D}: \mathrm{B}, \triangle, \Delta: \mathrm{C}, \square, \boldsymbol{\square}: \mathrm{D}$,

$\oslash, \boldsymbol{\sigma}: \mathrm{E}, \quad \mathrm{O}, \bigcirc: \mathrm{F}, \nabla, \nabla: \mathrm{G}, \diamond, \diamond: \mathrm{H}$

$0, \square, \triangle, \square, \varnothing, 0, \nabla, \diamond:$ Direct activation of coal

$\boldsymbol{\square}, \Delta, \boldsymbol{\square}, \boldsymbol{\Theta}, \boldsymbol{\nabla}, \odot:$ Activation of char

$S_{\mathrm{g}}\left(\mathrm{m}^{2} / \mathrm{g}\right)$

(a) : 500, (b) : 1000, (c) : 1500

なお，以下の実験結果で, 温度・時間条件の表示を, 昇温操作 では, 初期温度 ${ }^{\circ} \mathrm{C}$. 界温速度 $\left({ }^{\circ} \mathrm{C} / \mathrm{min}\right) \cdot$ 上限 $t_{\mathrm{f}}{ }^{\circ} \mathrm{C}$. 上限江拈 る保持時間 $[\mathrm{hr}]$ ，また，定温操作では，温度 ${ }^{\circ} \mathrm{C}$ ・保持時間 $[\mathrm{hr}]$ の順に（）や［]を用いて略記しだ。

\section{1 直接賕活}

因 2 と図 3 は，原料石炭を炭化工程を省き，900号で直接，ス チーム賦活を 0.5〜7 時間行なった場合の細孔開発（赋活進行） による取率 $Y$ の低下にともなら装面積 $S_{\mathrm{g}}$ の增減の様相を示した るのである。図2からわかるように倵活進行経路は，すへての石 孷について，ほほ類似の直線的傾向が得られ，ちなみに，2３出 よび 5 時間処理の 21 溯のデータを用いた回㷌分析の結果, 相関 保数 0.828 の精度で次式が得られた。

$$
S_{\mathrm{p}}=Y S_{\mathrm{g}}=486.86-502.62 Y
$$

しかし，固定炭雲分之灰分の含有率の罢なる各石炭について劷 しく考察してみると，炭化度の低い石炭（A，B，C)では，2５ 㭙間の直接倵活で $S_{\mathrm{g}}$ が $500 \sim 1000 \mathrm{~m}^{2} / \mathrm{g}$ の活性炭が得られるが， 他方，炭化度の高い石炭では，5時間の值接漹活によっても， $S_{\mathbf{g}}$ が $500 \mathrm{~m}^{2} / \mathrm{g}$ 以上のものを得ることはむずかしいようである（図 $3:$ 速度論的な検討については後で述べる)。

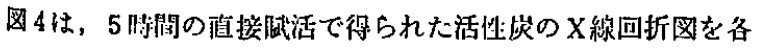
石炭について比校したもので， $Y$ は 22〜66\%， $S_{\mathrm{g}}$ は 160〜1920 $\mathrm{m}^{2} / \mathrm{g}$ と大きく相造しているが，図1に示した原料石芿とくらべ ると，基本的な辈造烄化はほとしどみられないことが知られる。

\section{2 乾式炭化之賦活}

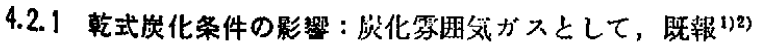
18) $S_{\mathrm{g}}=486.86 / Y-502.62 ; S_{\mathrm{g}}=800$ で $Y=0.374$ となる.

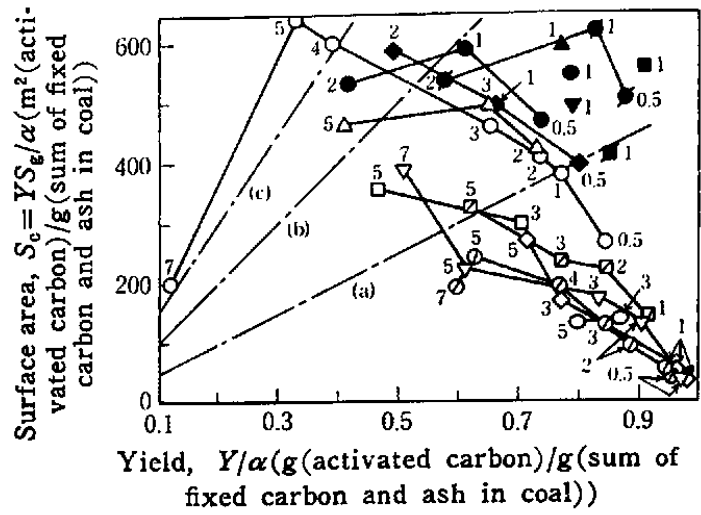

Fig. 3 Direct activation of coal and activation of char carbonized by wet method

Activation : $\mathrm{H}_{2} \mathrm{O}(10 \%)-\mathrm{N}_{2}, 900^{\circ} \mathrm{C}, 0.5 \sim 7 \mathrm{hr}$ Marks and parameter, etc.: Referred to Fig. 2 $S_{\mathrm{g}}\left(\mathrm{m}^{2} / \mathrm{g}\right)$

(a) : 500, (b ) : 1000, (c) : 1500

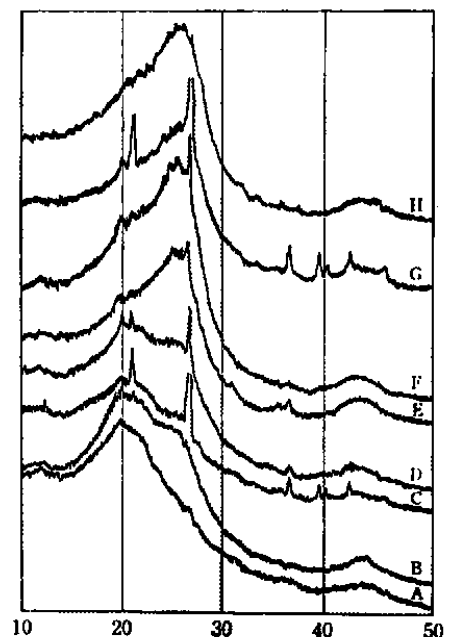

Diffraction angle, $2 \theta\left(\mathrm{Cu} K_{\alpha}\right)$ (degree)

Fig. $4 \mathrm{X}$-ray diffractograms of activated carbon prepared by direct activation of coal

Activation : $\mathrm{H}_{2} \mathrm{O}(10 \%)-\mathrm{N}_{2}, 900^{\circ} \mathrm{C}, 5 \mathrm{hr}$

Yield, $Y(\mathrm{~g}$ (activated carbon) $/ \mathbf{g}$ (coal))

$A: 0.219, B: 0.305, C: 0.300, D: 0.453$,

$\mathrm{E}: 0.500, \mathrm{~F}: 0.664, \mathrm{G}: 0.529, \mathrm{H}: 0.639$

Surface area, $S_{\mathrm{g}}\left(\mathrm{m}^{2} / \mathrm{g}\right.$ (activated carbon))

$A: 1920, B: 780, C: 1120, D: 540$,

$\mathrm{E}: 390, \mathrm{~F}: 160, \mathrm{G}: 370, \mathrm{H}: 390$

のように，PVCなどのブラスチックを原料とする場合には，一 般に $\mathrm{CO}, \mathrm{H}_{2}$ などの還元性ガスや $\mathrm{N}_{2}$ より，空気(1)19), $\mathrm{Cl}_{2}{ }^{120)}$ ， $\mathrm{HCl}$-空気混合ガス ${ }^{2)}$ などの酸化性ガスの方が，難溶融・難黒鉛化 性の佂化物が得られやすく，かつ，此校的高い収率が得られる が(19)，石炭原料についてては， $\mathrm{N}_{2}{ }^{5)(0) 12)}$ 中空気(7)中での炭化の報告 はむるが，茏化雾囲気について記述のない報告が多く，同一の石 岑に対して系統的に炭化察囲気ガスの種類や温度などの異なった

19）大浴郎, 工化, 61, 447(1958).

20）鈴木弘茂，木村脩七，松井実，䈍協誌，76，131(1968). 


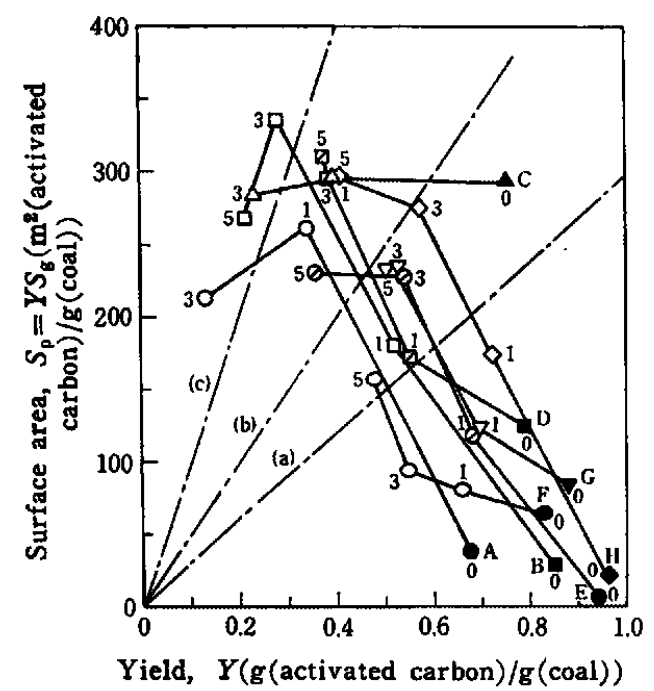

Fig. 5 Activation of char carbonized by dry method

Dry method : Treatment with air at room temp. (r.t.) $\left(4^{\circ} \mathrm{C} / \mathrm{min}\right) t_{\mathrm{f}}[3]^{*}$

\begin{tabular}{cccccccc} 
Coal : $A$ & B & C & D & E & F & G & H \\
\hline$t_{\mathrm{f}}\left({ }^{\circ} \mathrm{C}\right): 300$ & 350 & 350 & 380 & 350 & 400 & 400 & 350
\end{tabular}

Activation : $\mathrm{H}_{2} \mathrm{O}(10 \%)-\mathrm{N}_{2}, 900^{\circ} \mathrm{C}, 1 \sim 5 \mathrm{hr}$

*) r.t. $\left(4^{\circ} \mathrm{C} / \mathrm{min}\right) t_{\mathrm{r}}[3]$

r.t.: Starting temp., $\left(4^{\circ} \mathrm{C} / \mathrm{min}\right):$ rate of increasing temp. $t_{f}:$ Upper limit temp. ${ }^{\circ} \mathrm{C},[3]:$ Treatment time (hr) at $t_{\mathrm{f}}{ }^{\circ} \mathrm{C}$

$S_{\mathrm{g}}\left(\mathrm{m}^{2} / \mathrm{g}\right)-$

(a) : 300, (b) : 500, (c) : 1000

条件下で行なわれた報告は，䚾とんど見あたらない。

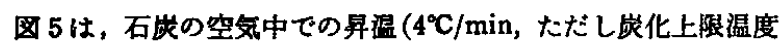
$t_{\mathrm{f}}$ はそれぞれ異なる) 炭化物を，同一条件 $\left(900^{\circ} \mathrm{C}\right)$ でスチーム賦 活した场合を比较したもので，図中の賦活時間 0は炭化物そのも のに相当する。 5 時闻の賦活でも $S_{\mathrm{g}}$ が $500 \mathrm{~m}^{2} / \mathrm{g}$ 以上のものが 得られない石炭 Fと G以外は， $S_{\mathrm{g}}$ が約 $800 \mathrm{~m}^{2} / \mathrm{g}$ のものか，35\% 程度の収率で得られる。また，炭化度の高い石炭とくらべると， 低い石炭 $(\mathbf{A}, \mathbf{B}, \mathbf{C})$ ほど, 短時問の賦活で緗孔開発が進行する傾 向にあることが知られる。

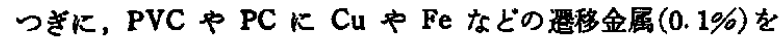
付着させて $\mathrm{HCl}$-空氛ガス中で炭化すると, 脱 $\mathrm{HCl}$ 反応と酸化 塩类化の併起によって難黑鉛化性ハードカーボンの生成が促進さ れ，活性炭帆率が向上する奻果が誌められた2)ので、この手法を 原料石炭に対して武みてみた。まず，石炭中の灰分などの Deacon 反応 $\left(4 \mathrm{HCl}+\mathrm{O}_{2} \longrightarrow 2 \mathrm{Cl}_{2}+2 \mathrm{H}_{2} \mathrm{O}\right)$ 飞対する触媒能の 程度を知るために, 熱テンビンによる空気と, $\mathrm{HCl}$-空気混合が ス気流中ての早温熱重量变化分析を行ない，その結果を図6に示 した。すなわち空気気流中でのいらじるしい減量(揮発・ガス化) の開始温度は，石能の炭化度の高くなるにしたがい, 順次, 高く なるが， $N_{2}$ 気流中での值（表 2 中の $t_{\mathrm{d}}$ ） と大同小異である。し かし，HCl一空気混合ガス流中では，減量の開始温度は，炭化度の

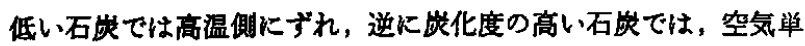
独の場合上り重甾減少が低温から開始する㑯向を示し, 石炭 D Gでは，この減量開始温度と減量速度ともに，ほとんど差哄は認

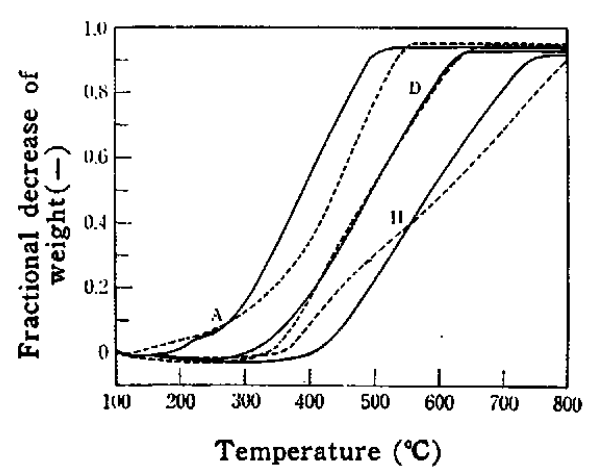

Fig. 6 Weight decrease through volatilization-carbonization-gasification of $\operatorname{coal}(\mathrm{A}, \mathrm{D}, \mathrm{H})$ in air and $\mathrm{HCl}$ $(5 \%)$-air stream

Programmed temp.: $4^{\circ} \mathrm{C} / \mathrm{min}$ from $110^{\circ} \mathrm{C}$ to $800^{\circ} \mathrm{C}$ — : Air, - - : : $\mathrm{HCl}(5 \%)$-air

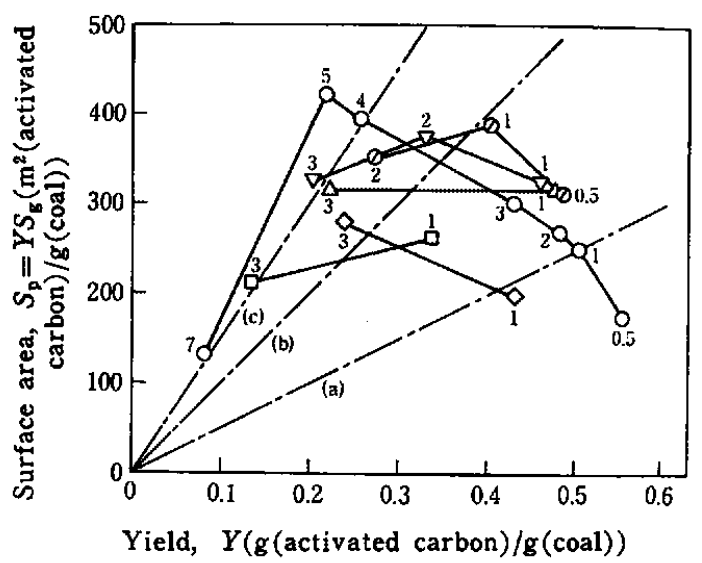

Fig. 7 Comparison of direct activation of coal $A$ with activations of char carbonized by wet method and dry method from coal $A$

Sample Carbonization

Direct activation of coal

$\oslash$ Wet method : conc. $\mathrm{H}_{2} \mathrm{SO}_{4}, 150^{\circ}[1]$

$\square \quad$ Dry method : air, r.t. $\left(4^{\circ} \mathrm{C} / \mathrm{min}\right) 300^{\circ}[3]$

$\nabla \quad$ Dry method : $\mathrm{HCl}(5 \%)$-air, r. t. $\left(4^{\circ} \mathrm{C} / \mathrm{min}\right) 350^{\circ}[3]$

$\diamond \quad$ Dry method : $\mathrm{HCl}(5 \%)$-air, r.t. $\left(4^{\circ} \mathrm{C} / \mathrm{min}\right) 320^{\circ}[3]$

$\triangle$ Dry method : $\mathrm{CO}_{2}$, r.t. $\left(4^{\circ} \mathrm{C} / \mathrm{min}\right) 350^{\circ}[3]$

Activation : $\mathrm{H}_{2} \mathrm{O}(10 \%)-\mathrm{N}_{2}, 900^{\circ} \mathrm{C}, 0.5 \sim 7 \mathrm{hr}$ $S_{\mathrm{g}}\left(\mathrm{m}^{2} / \mathrm{g}\right)-$

(a) : 500, (b) : 1000, (c) : 1500

められなかった（図 6 および表 2 中の $t_{\mathrm{g}}$ )。

これらの結果に基ついて，炭化管囲気がスのみを空気のかわり に HCl-空気混合ガスに変え，さきの空気による能化物と同し条 件 $\left(900^{\circ} \mathrm{C}\right)$ でスチーム賦活して比較すると, 炭化度の低い石岸 $A$ (図 7)，B，Cでは， HCl-空気混合ガス中による炭化の方が空気 に上る炭化の場合上り，逆に炭化度の高い石崖 $(\mathrm{D} \sim \mathrm{H}:$ 図 8,9) では空気による炭化の方が，それぞれ $S_{\mathrm{p}}\left(=Y S_{\mathrm{g}}\right)$ が大きくなる ことが知られた。図 7〜9kは，HC1-空気混合ガスによる炭化の 場合の昇温上腿温度を变えた場合の絬果の一例む示してあり、こ 


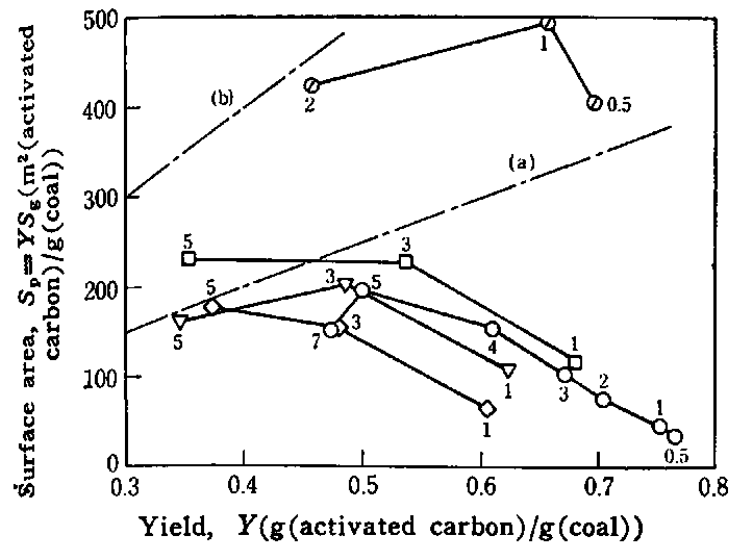

Fig. 8 Comparisons of direct activation of coal $\mathrm{E}$ with activations of char carbonized by wet and dry method from coal $E$

Sample Carbonization

0 Direct activation of coal

$\oslash$ Wet method : conc. $\mathrm{H}_{2} \mathrm{SO}_{6}, 150^{\circ}[1]$

$\square \quad$ Dry method : air, r.t. $\left(4^{\circ} \mathrm{C} / \mathrm{min}\right) 350^{\circ}[3]$

$\nabla \quad$ Dry method : $\mathrm{HCl}(5 \%)-\mathrm{air}$, r.t. $\left(4^{\circ} \mathrm{C} / \mathrm{min}\right) 350^{\circ}[3]$

$\diamond \quad$ Dry method : $\mathrm{HCl}(5 \%)$-air, r.t. $\left(4^{\circ} \mathrm{C} / \mathrm{min}\right) 400^{\circ}[3]$ Activation : $\mathrm{H}_{2} \mathrm{O}(10 \%)=\mathrm{N}_{2}, 900^{\circ} \mathrm{C}, 0.5 \sim 7 \mathrm{hr}$ $S_{\mathrm{g}}\left(\mathrm{m}^{2} / \mathrm{g}\right)-$

(a) : 500, (b) $: 1000$

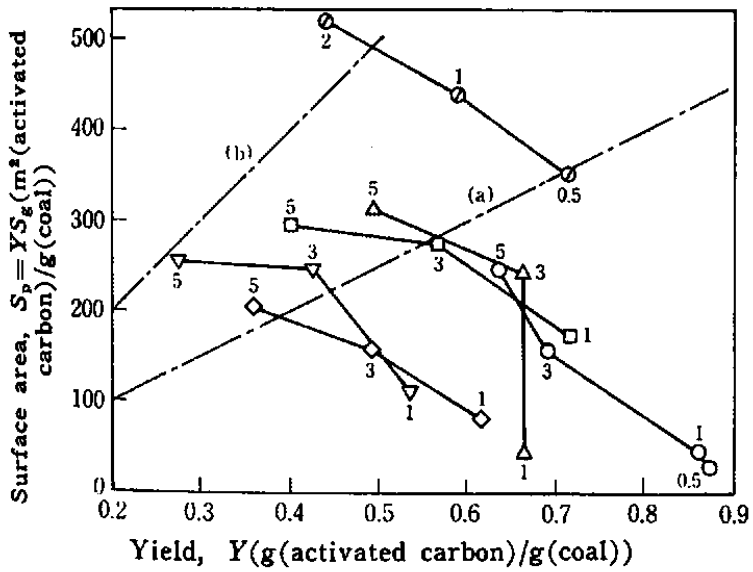

Fig. 9 Comparisons of direct activation of coal $\mathbf{H}$ and activation of char carbonized by wet or dry method from coal $\mathrm{H}$

\begin{tabular}{ll} 
Sample & Carbonization \\
\hline$O$ & Direct activation of coal \\
$\oslash$ & Wet method : conc. $\mathrm{H}_{2} \mathrm{SO}_{4}, 150^{\circ}[1]$ \\
$\square$ & Dry method : air, r.t. $\left(4^{\circ} \mathrm{C} / \mathrm{min}\right) 350^{\circ}[3]$ \\
$\nabla$ & Dry method : $\mathrm{HCl}(5 \%)-\mathrm{air}$, r.t. $\left(4^{\circ} \mathrm{C} / \mathrm{min}\right) 350^{\circ}[3]$ \\
$\diamond \quad$ Dry method : $\mathrm{HCl}(5 \%)-$ air, r.t. $\left(4^{\circ} \mathrm{C} / \mathrm{min}\right) 400^{\circ}[3]$ \\
$\triangle \quad$ Dry method : $\mathrm{CO}_{2}$, r.t. $\left(4^{\circ} \mathrm{C} / \mathrm{min}\right) 350^{\circ}[3]$ \\
Activation : $\mathrm{H}_{2} \mathrm{O}(10 \%)-\mathrm{N}_{2}, 900^{\circ} \mathrm{C}, 0.5 \sim 5 \mathrm{hr}$ \\
$S_{\mathrm{g}}\left(\mathrm{m}^{2} / \mathrm{g}\right)-$
\end{tabular}

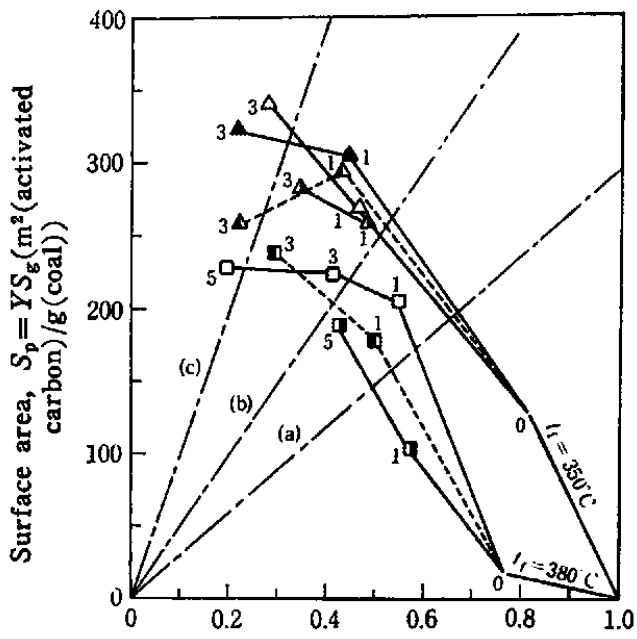

Yield, $Y$ (g(activated carbon) $/ g$ (coal))

Fig. 10 Effect of gas component on activation of char carbonized by dry method

Carbonization : $\mathrm{HCl}(5 \%)-\mathrm{air}$, r.t. $\left(4^{\circ} \mathrm{C} / \mathrm{min}\right) t_{\mathrm{f}}[3]$ Activation gas -

$\triangle \square: \mathrm{H}_{2} \mathrm{O}(10 \%)-\mathrm{N}_{2}, \triangle: \mathrm{H}_{2} \mathrm{O}(20 \%)-\mathrm{N}_{2}$,

$\triangle, \square: \mathrm{CO}_{2}, \triangle, \mathrm{D}: \mathrm{H}_{2} \mathrm{O}(10 \%)-\mathrm{CO}_{2}(55 \%)-\mathrm{N}_{2}$ Activation temp. and time : $900^{\circ} \mathrm{C}, 1 \sim 5 \mathrm{hr}$ $S_{\mathrm{g}}\left(\mathrm{m}^{2} / \mathrm{g}\right)$

(a) : 300 , (b) : 500, (c) : 1000

れらの $S_{\mathrm{p}}$ † に対する影部は非常に微妙であり，炭化度の低 い石炭では減量開始温度より，若干，高温矌で，また炭化度の高 い石宸では，むしろ，わずか低温側で岸化する方が，好ましい結 果が得られる傾向にあった。

さて, 図 6 中の石嵌 A と Hの減量の様相は, PVC と PC K Fe (0.1\%) を添加したものの空気と HCl-空気混合ガス中の年温減 量の様相とまったく類似しており2)，また HCl一空気渑合ガスに

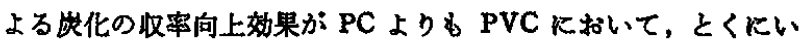
らじるしかったこと，原料中の宸莱含有率が PVC の方が PC 上

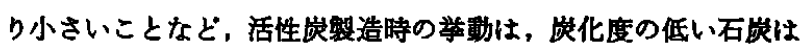
PVC の場合に，炭化度の高い石炭は PCの堨合に，それぞれ符 合する点が多い上うに思われ興味深い。

なお， $\mathrm{CO}_{2}$ 雾围気流中の炭化も試みたが，相対的にはすぐれて いる炭化度の低い石岸に対する $\mathrm{HCl}$-空気混合ガスによる炭化や 炭化度の高い石炭に対する空気による炭化の場合とくらべて，と くに有利と思われる点は見いだせなかった（図 7,9）。

4.2.2 賦活条件の検討：賦活ガスとして， $\mathrm{H}_{2} \mathrm{O}(10,20 \%)-\mathrm{N}_{2}$, $\mathrm{CO}_{2}, \mathrm{H}_{2} \mathrm{O}-\mathrm{CO}_{2}-\mathrm{N}_{2}$ を用いて検討した代表結果を図 10 に示した。 すなわち $\mathrm{CO}_{2}$ の賦活能は $\mathrm{H}_{2} \mathrm{O}(10 \%)-\mathrm{N}_{2}$ にくらべ, 収率には大 きな差巽はないが，細孔開袠能に之しく，生成活性炭の表面啨 $S_{\mathrm{g}}$ はつねに小さい。水蒸気濃度，10\% と $20 \%$ の埸合をくらべ ると短時間ではあまり変わらないが，高漫度では，倵活のしすぎ による表面皘の減少を招きやすく，賦活時間の選定に細かい、注意 が必要となり，本研究では $10 \% \mathrm{H}_{2} \mathrm{O}-\mathrm{N}_{2}$ を主として用いた。

因 11 は，700，800 および $900^{\circ} \mathrm{C}$ について，それぞれ時間を変 えて $\mathrm{H}_{2} \mathrm{O}-\mathrm{N}_{2}$ で賦活した場合の結果であり，図中，石炭Aの 700 ${ }^{\circ} \mathrm{C}$ に扣ける 1 時間と 3 時間の賦活結果にみられるように, 低温 


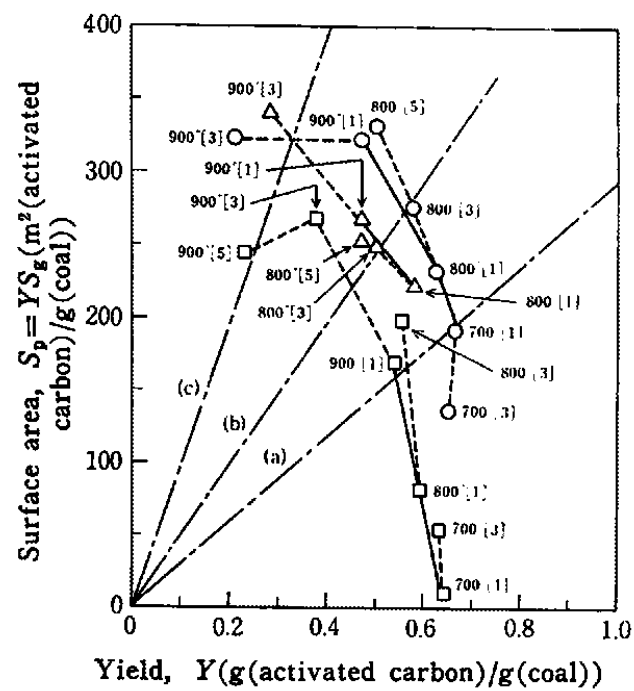

Fig. 11 Effects of temperature and time on activation of char carbonized by dry method

Carbonization : $\mathrm{HCl}(5 \%)$-air, r.t. $\left(4^{\circ} \mathrm{C} / \mathrm{min}\right) 350^{\circ}[3]$

Activation : $\mathrm{H}_{2} \mathrm{O}(10 \%)-\mathrm{N}_{2}, 700 \sim 900^{\circ} \mathrm{C}, 1 \sim 5 \mathrm{hr}$

Coal-

$\mathrm{O}: \mathrm{A}, \square: \mathrm{B}, \triangle: \mathrm{C}$

$S_{\mathrm{g}}\left(\mathrm{m}^{2} / \mathrm{g}\right)$

(a) : 300, (b) $: 500$, (c) $: 1000$

度下の長時間賦活では，ガス化能の不足に起因して収率は変わら ないむのの $S_{\mathrm{g}}$ の低下を示す场合があり，むしろ高温 $\left(900^{\circ} \mathrm{C}\right) \cdot$ 短時間賦活が望ましい頋何にあった。このことは PVCゃ PCを 原料とする場合と同じである2)。

乾式炭化と賦活の 2 段の工程を経て生成された活性炭のX線回 折図は，因 4 に示した值接賦活によるものと類似しており，この ことは炭化および䳢活（細孔開発）進行に門関係に，原料石炭の 基本的な炭素槽造を保持していることを示しているものと思われ る。

以上のように，炭化度の低い石炭については，直接倵活あるい は空気， $\mathrm{HCl}$-空気混合ガスによる幹式炭化と高温 $\left(900^{\circ} \mathrm{C}\right.$ 付近 $)$ におけるスチーム倵活の 2 段の工程により，此較的容易に市肘活 珄炭に相当する $S_{\mathbf{g}}$ をむつものを得ることができたが，炭化度が 高く，粘結性を有する石炭では，賦活時のガス化にともなう細孔 開発が有效に行なわれがたく，賦活時間を長くすることなどによ って $S_{\mathrm{B}}$ の大きいものを得ることはできても，その収染はきわめ て低くなる佰向にある(図 2,8)。この点の改良法として，つぎに 熱渺硫酸に上る湿式炭化の適否を検得した。

\section{3 湿式炭化と賳活}

4.3.1 湿式炭化物の眮活：石炭の熱漫硫酸による処理は，陽 イオン交換剤を製造する方法の一つとして，古くから検討されて おり，とくに浦野ら ${ }^{14)}$ の 18 種の国内崖の処理条件と製荘の強・ 弱酸性陽イオン交換容量やメタノール吸着法による細孔分布など の詳細な報告がある。石炭の硫酸処理によってスルホン化反㾂ば かりでなく，酸化反応も同時に起こり，カルボキシル基などを生

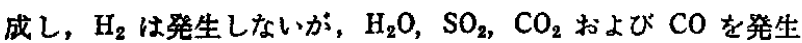
オる ${ }^{14)}$

本研究では，この硫酸処理を石炭の炭化の一方法とみなして，

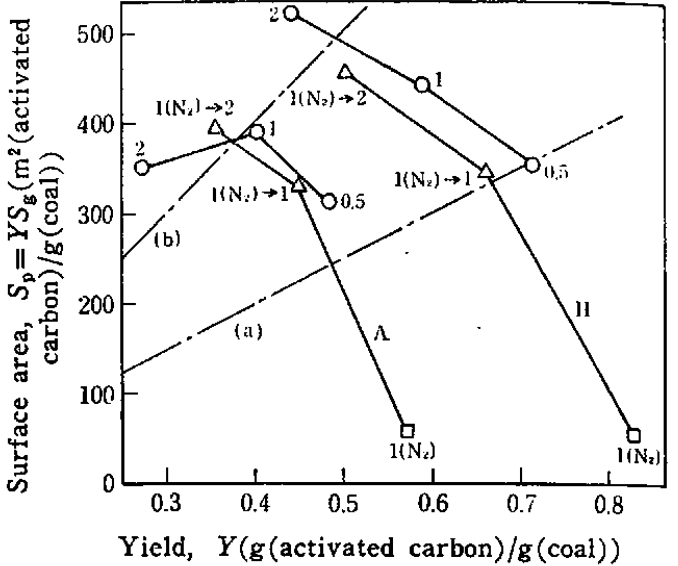

Fig. 12 Effects of pretreatment with $\mathrm{N}_{2}$ on activation of char carbonized from coal $\mathrm{A}$ and $\mathrm{H}$ by wet method

Carbonization : conc. $\mathrm{H}_{2} \mathrm{SO}_{4}\left(200 \mathrm{ml} / 20 \mathrm{~g}\right.$ (coal)), $150^{\circ}[1]$

$\square$ : Pretreatment with $\mathrm{N}_{2}: 900^{\circ} \mathrm{C}, 1 \mathrm{hr}$

$\mathrm{O}$ : Activation : $\mathrm{H}_{2} \mathrm{O}(10 \%)-\mathrm{N}_{2}, 900^{\circ} \mathrm{C}, 0.5 \sim 2 \mathrm{hr}$

$\triangle$ : Activation with $\mathrm{H}_{2} \mathrm{O}(10 \%)-\mathrm{N}_{2}$ at $900^{\circ} \mathrm{C}$ for $1 \sim 2 \mathrm{hr}$ after treatment with $\mathrm{N}_{2}$ at $900^{\circ} \mathrm{C}$ for $1 \mathrm{hr}$ $S_{\mathrm{B}}\left(\mathrm{m}^{2} / \mathrm{g}\right)$

(a) : 500, (b) : 1000

たとえば $150^{\circ} \mathrm{C} ， 1$ 時間の処理を行なった絬果，水洗・畭燥(110 ${ }^{\circ} \mathrm{C}$ ，24 時間）後の炭化取察 $y_{\mathrm{c}}$ は，表 2 の右闑に示したよ5に， すべての石炭について1以上となり，スルホ基やカルボキシル 基などの付加が起こっている14)とと示唆した。これら同一条件 で処理して得た炭化物を，それぞれ $900^{\circ} \mathrm{C}$ で0.5〜2 時間（主と して 1 時間) スチーム陚活した結果を，図 2,3 に直接倵活による 結果と比較して示した。まず，これらの図から明らかなことは， 湿式炭化物の比較的短時間の倵活によって, 翌面積の大きい活性 炭が高い収率で得られることである。すなわち 0.5〜1 時間の短 㭙間赋活によって, $S_{\mathrm{g}}$ かi $500 \sim 800 \mathrm{~m}^{2} / \mathrm{g}$ の活性炭が $55 \sim 70 \%$ の収率 $(Y$; 図 2$)$ で，また，石炭中の固定炭辢分之兏分の和基

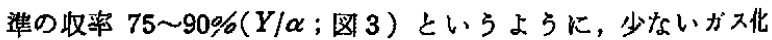
(炭慗損失)で細孔開発が有効にもたらされている。

さらに詳しく，石炭の種類について，この効㳭をみてみると， たとえば，1洔間賦活物に注目すると，直接赋活や乾式炭化によ っては, $S_{\mathrm{g}}$ が $500 \mathrm{~m}^{2} / \mathrm{g}$ 以上のものが得られにくい傾向にあっ た石炭 E，F， G，Hなどの粘結性炭や屍化度の高い石炭で，と くにすぐれた効果が認められた（図 7〜9）。

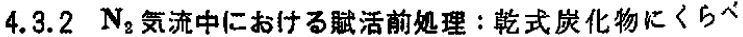
て，一般に高い取率で同程度の $S_{\mathrm{g}}$ をむつ活亚炭の得られる湿式 炭化物に刘して,さらに高収率化を目指し，スチーム陚活する前 に $\mathrm{N}_{2}$ 気流中で高溫熱処理 $\left(900^{\circ} \mathrm{C}\right)$ を行ないこの效果を众部し， 代表結果を図 12 亿示した。すなわち $\mathrm{N}_{2}$ の細孔開発能が，きわめ てそしいことは図 (口のデータ)から明らかであるが， $\mathrm{N}_{2}$ 箱流中 で前もって熱処理したのちにスチーム赋活すると，道常のように 炭化物をそのまま倵活した場合とくらべて同一倵活時間（1胿間 と 2 時間) でくらべて収率が向上し，場合によっては $S_{\mathrm{p}}$ む大き くなる場合も認められた(図12中の不炭 Aの 2 垨間倵活の埸合)。 


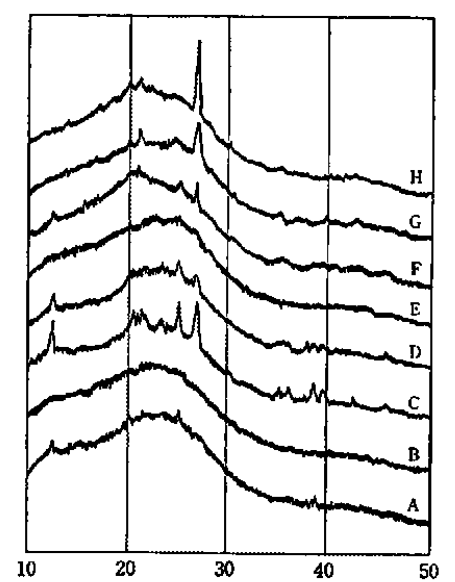

Diffraction angle, $2 \theta\left(\mathrm{Cu} K_{\alpha}\right)$ (degree)

Fig. $13 \mathrm{X}$-ray diffractograms of char carbonized by wet method

Carbonization : conc. $\mathrm{H}_{2} \mathrm{SO}_{4}, 150^{\circ}[1]$

このよらな現象や効果はPCの疢化物においてる，すでに認め られており2)，データは割愛したが，X線回折图の変化からも $\mathrm{N}_{2}$ 気流中での高温処理により黑鉛の (002) 面に相当する炭化物の炭 菜胘平面の尿間隔が狭くなった部分が発達し，部分的なグラフ イト化が起こっているためと考えられ20121，したがって，その後 のスチーム眠活反応（ガス化）速度は小さくなるるのの，炭素骨 挌が保持されやすくなり，取率低下が抑制されるむのと思われ $3 \%$

4.3.3炭化物と活性炭の X 線回折：硫酸処理による炭化物と その倵活物 (生成活性战)の代表例 $\left(\mathrm{H}_{2} \mathrm{O}(10 \%)-\mathrm{N}_{2}\right.$ による $900^{\circ} \mathrm{C}$, 1 洔間の賦活物：因 2 あるいは図 3 参照) のX線回折図をそれぞ れ図13 と図14に示した。湿式灰化物では，図1に示した原料石 炭の場合とくらべて明らかな变化は，炭化度の高い石炭に認めら れた回折角 $26^{\circ}$ 付近のビークが消失し，また炭化度の低い石炭て 琵められた $20^{\circ}$ 付近のビークが若干，高角側に移ったことであ ク，結果的には原料石炭による盖異はほとんどみられなくなって

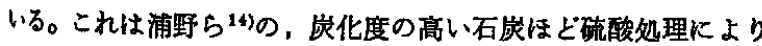
䋃孔分布に大きな变化をらけ，イオン交換体（本研究の炭化物） のもつ絴孔分布の原料石岸の種類による差異が小さくなった結果 に対馆しているむのと思われる。

炭化度の高い石炭で炭素網平面の間隔が少し広くなった炭化物 の炭素搆造は，生成した活性炭にも，そのまま，受けつがれて抽 り(図 14)，活性炭の炭素構造は倵活によってはあまり大きな变 化をらけず（るらろん，極端に賦活しすぎると，綀孔開発にした がって度，発達したピークがまた小さくなり，回折角す低角側 に移った；図 2 で石炭 A の直接賦活の 5 時間と 7 時間の場合), この点は，既述の乾式炭化の場合と同じである。したがって，一 般飞生成活性炭の基本的な炭素構造は炭化物の棈造, すなわち宸 化负件・方法によって決定されているといえる。このようにX線 回折にみられる丵造は乾式法と湿式法で異なっている（因 4 と図 14）が，炭化物の倵活能や生成活性炭の吸着能には，なんらの差 巽もみられなかっだ。この点については後でも述べる。

21）川角正八，江頭誠，宇野克产，日化，1979，403.

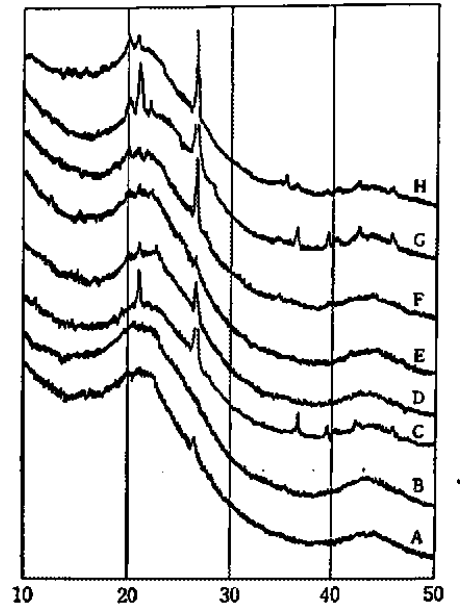

Diffraction angle, $2 \theta\left(\mathrm{Cu} K_{\alpha}\right)$ (degree)

Fig. $14 \mathrm{X}$-ray diffractograms of activated carbon prepared from char carbonized by wet method

Carbonization : conc. $\mathrm{H}_{2} \mathrm{SO}_{4}, 150^{\circ}[1]$ Activation : $\mathrm{H}_{2} \mathrm{O}(10 \%)-\mathrm{N}_{2}, 900^{\circ} \mathrm{C}, 1 \mathrm{hr}$ Yield, $Y$ (g(activated carbon) $/ g$ (coal))

$A: 0.404, B: 0.592, C: 0.560, D: 0.623$,

$\mathrm{E}: 0.658, \mathrm{~F}: 0.654, \mathrm{G}: 0.680, \mathrm{H}: 0.590$

Surface area, $S_{\mathrm{g}}\left(\mathrm{m}^{2} / \mathrm{g}\right.$ (activated carbon))

$A: 960, B: 610, C: 770, D: 480$

E : 750, F : 690, G : 620, H : 750

\section{4 賳活反応速度}

図 2 や図 7 9から，同し製造条件では，石岸の種類によって， また同一石炭においては，灰化の方法や条件によって賦活経路が 巽なるばかりでなく，同じ程度の $S_{\mathrm{g}}$ が得られるまでの賦活時 間，すなわち石宸や炭化物の賦活ガスとの反応性も大きく县なっ てくることがわかる。本研究で行なった石奜に対する空知および HC1-空気混合ガスによる乾式炭化物，惯硫酸による湿式此化物 および石炭そのもののスチーム赋活 $\left(900^{\circ} \mathrm{C}\right)$ の収率 $Y$ と賦活時間 $\theta$ の関傒は，検討の結果，すべての石炭について見かけ上，一次 反応として整理できた。

$$
k \theta=-\ln Y
$$

この適合性の代表結果を，用いた石炭中で炭化度のもっとも低 いAともっとも高いHについて,それぞれ図 15 と図16に示した。 賦活開始直後の急激な収率の呧下は，揮発分の寄与が大きく，腃 化度の低い石炭ではとくにいちしるしく，その以後の比較的粭中 かな勾配部分が，固定炭菜のガス化によるるのである。図 17 は 直線の勾配と(2)式から求めた一次反応速度定数 $k(1 / \mathrm{hr})$ を原料 石炭の炭化度（燃料比）に対して点矧したものである。図中の○ 印は石炭の面接賦活の場合であるが， $k$ の值は炭化度の低い石炭 A，B，Cについては F.C./V.M. 比が大きくなると低下する佰 向にあり，他方，炭化度の高い石炭では炭化度にほぼ無関係な一 定值を示し，举動は明らかに異なっている。の肮は，本研究より さらに炭化度の低い領域の石炭 (褐岸) を原料とする既往文献中，

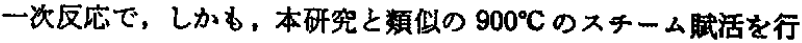

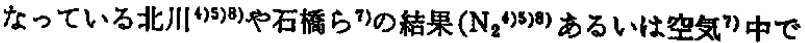
の乾式崖化物の倵活；F.C./V.M. 比は表 1 を参照）から再計算 


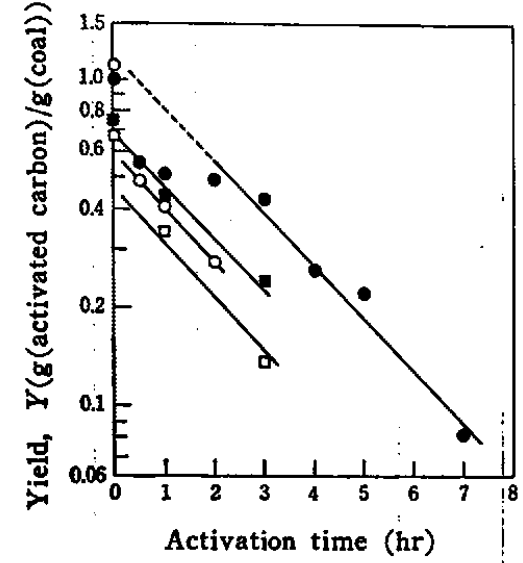

Fig. 15 First-order reaction plots of activations of coal $A$ and its char

\begin{tabular}{cl} 
Sample & \multicolumn{1}{c}{ Carbonization } \\
\hline & Direct activation of coal \\
Wet method : conc. $\mathrm{H}_{2} \mathrm{SO}_{4}, 150^{\circ}[1]$ \\
$\square$ & Dry method : air, r. t. $\left(4^{\circ} \mathrm{C} / \mathrm{min}\right) 300^{\circ}[3]$ \\
& Dry method : $\mathrm{HCl}(5 \%)-$ air, r. t. $\left(4^{\circ} \mathrm{C} / \mathrm{min}\right) 320^{\circ}[3]$
\end{tabular}
Activation : $\mathrm{H}_{2} \mathrm{O}(10 \%)-\mathrm{N}_{2}, \cdot 900^{\circ} \mathrm{C}$

\section{したものである。}

さて，興味㳭いことは，F.C./V.M. 比が 3:0以下で， $\log k$ 対 $\log$ (F.C./V.M.) が值線閂係を示しており，もっとるかけ離れて いるつ 4 個のデータを省いた○印と○印の合計 9 個のデータに 就して，相闻保数 0.964 で，(3)式を得た。

$$
\begin{array}{ll}
\because k & k=2.31 \text { (F. C. } / \text { V.M. })^{-8.22} \quad(1 / \mathrm{hr}) \\
\because \quad & \text { F.C. /V.M. }=0.8 \sim 3
\end{array}
$$

また， $\log k$ は， $\log \alpha$ に対してもほほ同槏な成係を示し，相 成俰 0.946 の次式が得られた。

$$
\begin{array}{ll}
\because & k=5.53 \times 10^{-15} \alpha^{-8.9}(1 / \mathrm{hr}) \\
\because & \alpha=50 \sim 75 \%
\end{array}
$$

高い峞化度の領域では，大咯值ではあるが，つぎのような体が 得られた。

$$
\begin{array}{lll}
\therefore & k \fallingdotseq 0.09(1 / \mathrm{hr}) \\
\therefore & & \text { F. C. } / \text { V. M. }=3 \sim 8 \\
\therefore & \because \quad \alpha=75 \sim 90 \%
\end{array}
$$

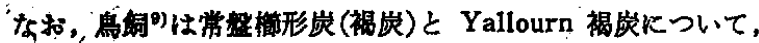
$\mathrm{CO}_{2}$ Kよる直接賦活 $\left(700 \sim 950^{\circ} \mathrm{C}\right)$ を行なった結果，収率 $Y$ に関 して0次反応であったと報告している。他方， $\mathrm{PVC}^{22) 28)}, \mathrm{PC}^{24)}$,

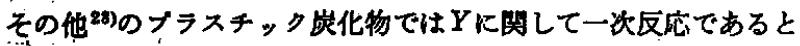
いう数告が多い。

図 17 中の $\triangle$ 用は䏠式炭化物の㒃活の場合で，空気による岸化 物と HCl-空気混合ガスによる炭化物とでは，ほとんど倳がみ

22) 井口等，角田一，竹下三吉，日化，1973，1627.

23)! 北川 浩, 日化, 1974, 1336.

24). 北州(浩, 日化, 1974, 366.

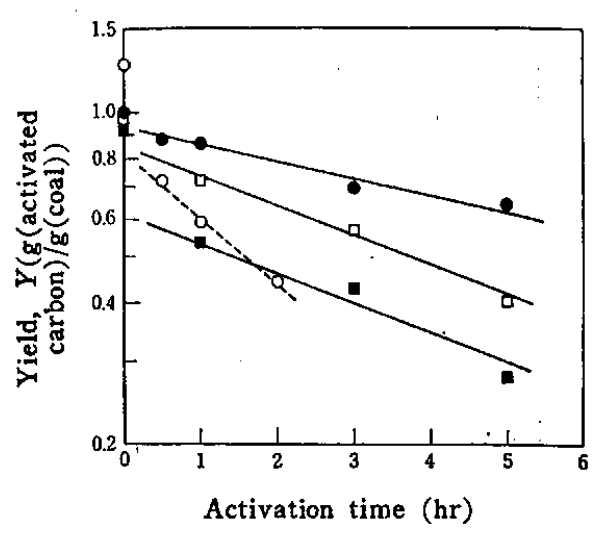

Fig. 16 First-order reaction plots of activations of coal $H$ and its char

\begin{tabular}{cl} 
Sample & \multicolumn{1}{c}{ Carbonization } \\
\hline & Direct activation of coal \\
$\mathrm{O}$ & Wet method : conc. $\mathrm{H}_{2} \mathrm{SO}_{4}, 150^{\circ}[1]$ \\
$\square$ & Dry method : atr, r. t. $\left(4^{\circ} \mathrm{C} / \mathrm{min}\right) 350^{\circ}[3]$ \\
Dry method : $\mathrm{HCl}(5 \%)-$ air, r.t. $\left(4^{\circ} \mathrm{C} / \mathrm{min}\right) 350^{\circ}[3]$ \\
Activation : $\mathrm{H}_{2} \mathrm{O}(10 \%)-\mathrm{N}_{2}, 900^{\circ} \mathrm{C}$
\end{tabular}

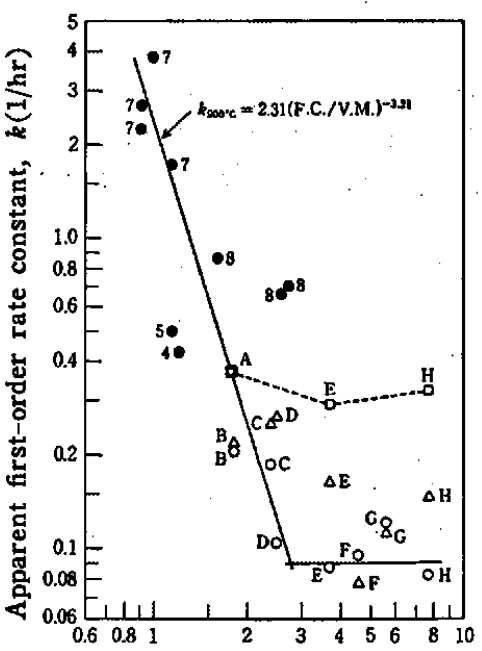

Ratio of fixed carbon(F.C.) to volatile matter(V.M.) in coal ( $\mathrm{g} / \mathrm{g})$

Fig. 17 Relations between steam-activation activities of coal and char and ratio of F.C./V.M. in raw coal

\section{Sample}

$0:$ Direct activation coal

$\square$ : Char carbonized by wet method

$\triangle:$ Char carbonized by dry method

: Char carbonized by dry method found in literatures
Fig. and Table to be referred

Fig. 2

Fig. 7, 8, 9

Fig. 5

Table 1
られなかった（図 15,16）が， $k$ の值を既述の直接殷活の場合と くらべると一般に大きく，とくに石炭 D， E，Hでは2 倍程度に なっている。また，図 17 中の四印は湿式炭化物の賦活の埸合て ある。炭化度が低く，かつ非粘結性の石炭Aでは, 図 15 にる示

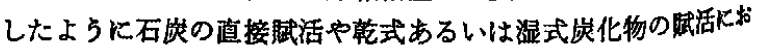




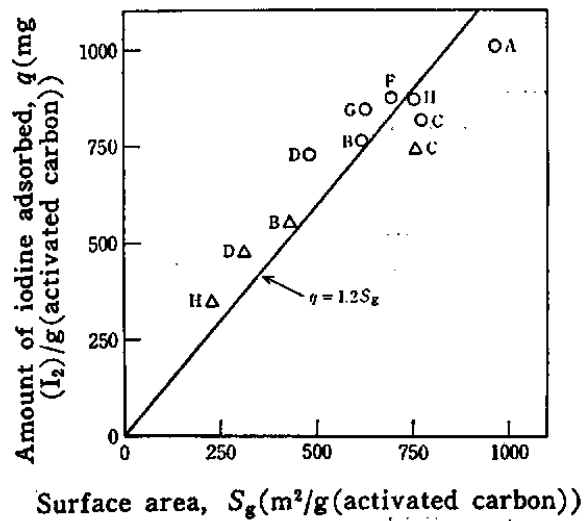

Fig. 18 Adsorption of iodine(liquid phase) on activated. carbon prepared by direct activation of coal and activation of char carbonized by wet method

\begin{tabular}{ll}
\multicolumn{1}{c}{ Carbonization } & \multicolumn{1}{c}{ Activation } \\
\hline $\mathrm{O}:$ conc. $\mathrm{H}_{2} \mathrm{SO}_{4}, 150^{\circ}[1]$ & $\mathrm{H}_{2} \mathrm{O}(10 \%)-\mathrm{N}_{2}, 900^{\circ} \mathrm{C}, 3 \mathrm{hr}$ \\
$\mathrm{H}_{2} \mathrm{O}(10 \%)-\mathrm{N}_{2}, 900^{\circ} \mathrm{C}, 1 \mathrm{hr}$
\end{tabular}

してもとの反応泩は、汪とんと变わらないのに対して炭化度が高 く，かつ强粘結性の石炭 $\mathrm{E}+2$ び炭化度が高く，かつ非粘結性の

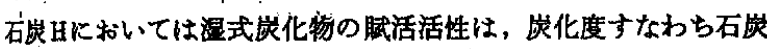

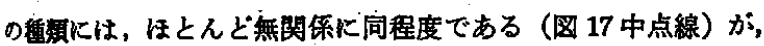
直接珹活の場合の 3 倍程度以上にも增大することが認められた。 硫酸処理後の石炭の酸素含有率の增加が炭化度の高い石岸はど レらしるしく多いといら浦野ら"4)の報告は，この眠活活性向上の 要肉を示唆しており，kの値と灰分含量とはなんら相関性が認め られなかったことから，灰分中の $\mathrm{Fe}, \mathrm{Co}, \mathrm{Ca}, \mathrm{Na}$ などの無機

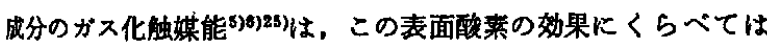
るかて劣っているものと思われる。

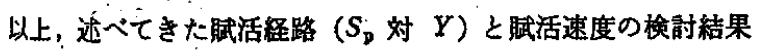
を，表面碛の大きい活性炭を高い收率で得るための至適条件を知 万面から総括してみると，特殊な細孔分布，特殊な化学的性質， 信的強度を含めた造粒性などの実用化に対する娭討の余地恃， まだまだ残されていると思われるが，原理的には原料石岑の

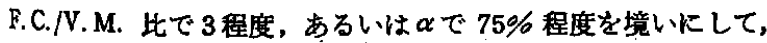
岸化度の低い石炭では炭化工程を省いた直接開活か，また能化度 の高い石炭では愁浱硫酸による湿式炭化物の賦活による2 段処理 法かすくれているといえる。

\section{5 生成活性炭の吸兼能}

代表的な生成活性炭の $\mathrm{I}_{2}$ (分子状)， $\mathrm{UO}_{2}{ }^{2+}$ (正䉓荷イオン)於よ

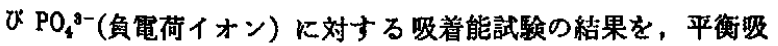

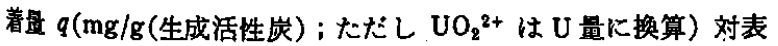

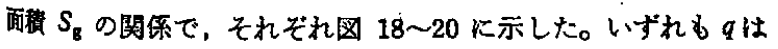
$S_{\mathbf{g}}$ k比例し，それぞれつぎの式で大略，相関された。

$$
\begin{aligned}
& \left.q\left(\mathrm{mg}\left(\mathrm{I}_{2}\right) / \mathrm{g} \text { (生成活性炭 }\right)\right)=1.20 \mathrm{~S}_{\mathrm{g}} \\
& q(\mathrm{mg}(\mathrm{U}) / \mathrm{g} \text { (生成活性炭 }))=0.18 \mathrm{~S}_{\mathrm{g}} \\
& \left.q\left(\mathrm{mg}\left(\mathrm{PO}_{4}{ }^{3-}\right) / \mathrm{g} \text { (生成活性崖 }\right)\right)=0.012 S_{\mathrm{g}}
\end{aligned}
$$

25）笠岡成光，阪田枯脌，山下弘文，西野微，然劦誌，58、 373(1979).

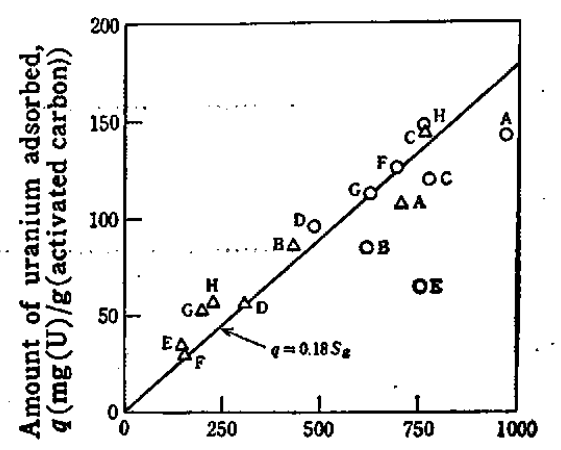

Surface area, $S_{\mathrm{g}}\left(\mathrm{m}^{2} / \mathrm{g}\right.$ (activated carbon))

Fig. 19 Adsorption of Uranium(liquid phase) on activated carbon prepared by direct activation of coal and activation of char carbonization by wet method

\begin{tabular}{cc} 
Carbonization & Activation \\
\hline$\triangle:$ & $-\mathrm{H}_{2} \mathrm{O}(10 \%)-\mathrm{N}_{2}, 900^{\circ} \mathrm{C}, 3 \mathrm{hr}$ \\
$\mathrm{O}:$ conc. $\mathrm{H}_{2} \mathrm{SO}_{4}, 150^{\circ}[1]$ & $\mathrm{H}_{2} \mathrm{O}(10 \%)-\mathrm{N}_{2}, 900^{\circ} \mathrm{C}, 1 \mathrm{hr}$
\end{tabular}

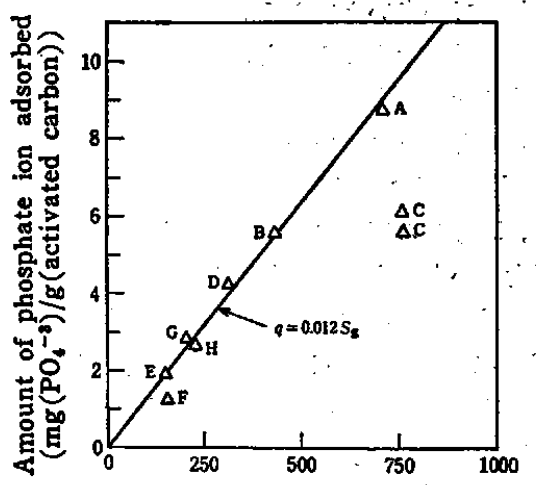

Surface area, $S_{\mathrm{g}}\left(\mathrm{m}^{2} / \mathrm{g}\right.$ (activated carbon))

Fig. 20 Adsorption of phosphate ion(liquid phase) on activated carbon prepared by direction activation of coal

Activation : $\mathrm{H}_{2} \mathrm{O}(10 \%)-\mathrm{N}_{2}, 900^{\circ} \mathrm{C}, 3 \mathrm{hr}$

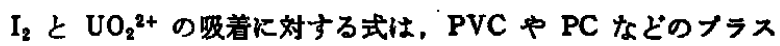
チックを原料とした活性能やキシガラ系活性峞に対しても成立し

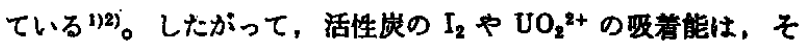
の原料，整造法・条件などあまり関保なく，むしろ物理的な表 面㯖だけで支部されていると教えられる。

他方， $\mathrm{PO}_{4}^{8-}$ の吸着に対する式は，PVCを原料之する場合の 次式にくらへて，単位表面精あたりの明着量 $q / S_{\mathrm{g}}$ は，2 倍大き w。

$$
\left.q\left(\mathrm{mg}\left(\mathrm{PO}_{4}^{\mathrm{s}-}\right) / \mathrm{g} \text { (生成活性炭 }\right)\right)=0.006 \mathrm{~S}_{\mathrm{g}}
$$

また， $\mathrm{PC}$ からの活性炭の $\mathrm{PO}_{4}^{8-}$ ，受着量性 $\mathrm{PVC}$ からの活性岸 より，さらに小さくなる傾向 $\left(q / S_{\boldsymbol{g}}<0.006\right)$ にあっだ)。このよ

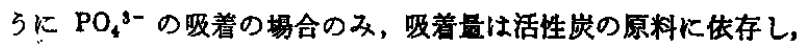
また $\mathrm{P}$ 原子の単位表面䅡 $\left(\mathrm{m}^{2}\right)$ あたりの曼着原子数 (mg-atom) は

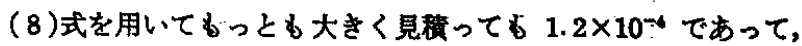
$\mathrm{U}\left(7.6 \times 10^{-4} \mathrm{mg}-\mathrm{atom} / \mathrm{m}^{2}\right) \neq \mathrm{I}\left(9.5 \times 10^{-1} \mathrm{mg}-\mathrm{atom} / \mathrm{m}^{2}\right) \mathrm{K}<$ 
Table 4 Catalytic activity of activated carbon prepared from coals for oxidation of $\mathrm{Fe}^{2+}$ solution with air

\begin{tabular}{|c|c|c|c|c|c|}
\hline Sample & \multicolumn{2}{|c|}{ Carbonization } & Activation & $S_{\mathrm{g}}{ }^{a}$ & $f^{b)}$ \\
\hline A : Collie & \multicolumn{3}{|c|}{ 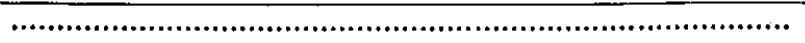 } & 2 & 0.025 \\
\hline A : Collie & $\mathrm{HCl}(5 \%)-\mathrm{Air}$ & $\operatorname{RT}\left(4^{\circ}\right) 320^{\circ}[3]$ & (n).......................... & 70 & 0.036 \\
\hline A : Collie & $\mathrm{HCl}(5 \%)-\mathrm{Air}$ & $\operatorname{RT}\left(4^{\circ}\right) 320^{\circ}[3]$ & $\mathrm{H}_{2} \mathrm{O}(10 \%)-\mathrm{N}_{2} ; 900^{\circ}[1]$ & 457 & 0.532 \\
\hline A : Collie & $\mathrm{HCl}(5 \%)-\mathrm{Air}$ & $\operatorname{RT}\left(4^{\circ}\right) 320^{\circ}[3]$ & $\mathrm{H}_{2} \mathrm{O}(10 \%)-\mathrm{N}_{2} ; 900^{\circ}[3]$ & 1173 & 0.895 \\
\hline B : Kellerman & \multicolumn{3}{|c|}{ 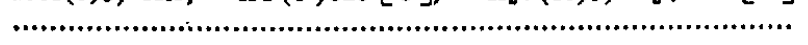 } & 0.7 & 0.053 \\
\hline B : Kellerman & \multirow{2}{*}{$\begin{array}{l}\mathrm{HCl}(5 \%)-\mathrm{Air}, \\
\mathrm{HCl}(5 \%)-\mathrm{Air},\end{array}$} & $\operatorname{RT}\left(4^{\circ}\right) 380^{\circ}[3]$ & 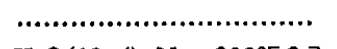 & 37 & 0.040 \\
\hline B : Kellerman & & $\operatorname{RT}\left(4^{\circ}\right) 380^{\circ}[3]$ & $\mathrm{H}_{2} \mathrm{O}(10 \%)-\mathrm{N}_{2} ; 900^{\circ}[3]$ & \multirow{2}{*}{$\begin{array}{r}686 \\
1230\end{array}$} & 0.955 \\
\hline C : Blair athol & \multirow{2}{*}{$\begin{array}{l}\mathrm{HCl}(5 \%)-\mathrm{Air} \\
\mathrm{Air},\end{array}$} & $\operatorname{RT}\left(4^{\circ}\right) 350^{\circ}[3]$ & $\mathrm{H}_{2} \mathrm{O}(10 \%)-\mathrm{N}_{2} ; 900^{\circ}[3]$ & & 0.861 \\
\hline D : S. Black water & & $\operatorname{RT}\left(4^{\circ}\right) 380^{\circ}[3]$ & $\mathrm{H}_{2} \mathrm{O}(10 \%)-\mathrm{N}_{2} ; 900^{\circ}[3]$ & 770 & 0.902 \\
\hline E : Pittstone & Air, & $\operatorname{RT}\left(4^{\circ}\right) 350^{\circ}[3]$ & $\mathrm{H}_{2} \mathrm{O}(10 \%)-\mathrm{N}_{2} ; 900^{\circ}[3]$ & 425 & 0.694 \\
\hline F : Keystone & Air, & $\operatorname{RT}\left(4^{\circ}\right) 400^{\circ}[3]$ & $\mathrm{H}_{2} \mathrm{O}(10 \%)-\mathrm{N}_{2} ; 900^{\circ}[3]$ & 170 & 0.508 \\
\hline G : Kuznetsk & Air, & $\operatorname{RT}\left(4^{\circ}\right) 400^{\circ}[3]$ & $\mathrm{H}_{2} \mathrm{O}(10 \%)-\mathrm{N}_{2} ; 900^{\circ}[3]$ & 446 & 0.734 \\
\hline H : Uonuki & \multicolumn{3}{|c|}{. } & 0.9 & 0.041 \\
\hline H : Uonuki & $\mathrm{HCl}(5 \%)-\mathrm{Air}$, & $\operatorname{RT}\left(4^{\circ}\right) 400^{\circ}[3]$ & 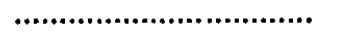 & 2 & 0.017 \\
\hline H : Uonuki & $\mathrm{HCl}(5 \%)-\mathrm{Air}$ & $\operatorname{RT}\left(4^{\circ}\right) 400^{\circ}[3]$ & $\mathrm{H}_{2} \mathrm{O}(10 \%)-\mathrm{N}_{2} ; 900^{\circ}[3]$ & 323 & 0.829 \\
\hline H : Uonuki & Air, & $\operatorname{RT}\left(4^{\circ}\right) 350^{\circ}[3]$ & $\mathrm{H}_{2} \mathrm{O}(10 \%)-\mathrm{N}_{2} ; 900^{\circ}[3]$ & \multirow{2}{*}{$\begin{array}{l}536 \\
910\end{array}$} & 0.886 \\
\hline Commercial activate & bon prepared & - 10 & & & 0.953 \\
\hline
\end{tabular}

a) Specific surface area, $S_{\mathrm{g}}\left[\mathrm{m}^{2}\right.$ (activated carbon) $/ \mathrm{g}$ (activated carbon)].

b) Fractional oxidation of $\mathrm{Fe}^{2+}\left(\mathrm{FeSO}_{4}+(1 / 2) \mathrm{H}_{2} \mathrm{SO}_{4}+(1 / 4) \mathrm{O}_{2} \longrightarrow(1 / 2) \mathrm{Fe}_{2}\left(\mathrm{SO}_{4}\right)_{8}+(1 / 2) \mathrm{H}_{2} \mathrm{O}\right)$.

らべると，きわめて小さいといえる。

細孔分布の実澌結果をみてみると，一般にブラスチック系活性 宸は金属添加物のない場合あるいはあっても残留金属成分の少な い坦合はマク口細孔のみに近い一元的細孔分布 ${ }^{10222) 24) 26) て ゙ あ る の ~}$

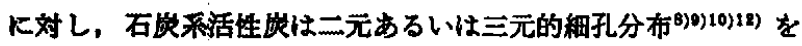

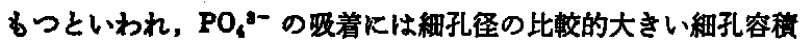
部分の奇与が大きいものと考えられるが, 目下, 明確でない。こ の上5な物理的な分子ふるい效果の上に，今後は活性炭がもつ $S_{\mathrm{g}}$ の大きいという特性を生かし，かつ岥素の表面あるい恃骨格 に特柘な化学的性質を付与する方法の開発が望まれる。

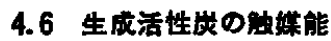

表 4 は $\mathrm{H}_{8} \mathrm{SO}_{4}$ 水溶液中の $\mathrm{Fe}^{2+}$ の空気酸化に対して, 新式笑化. 賦活による生成活性荻の螌媒能を，反応開始 10 時間後の $\mathrm{Fe}^{2+}$
の $\mathrm{Fe}^{s+}$ への酸化率 $f$ で対比したものである。比較のために一部, 原料石炭や倵活前の炭化物についても同様に検討した結果を示し たが，これらの酸化触媒能は，きわめて乏しいにもかかわらず， 倵活後の活性峞は，石炭の種類や表面㩌にもはは無関保にすぐれ た酸化触媒能を示し，表中，参考のために示した既報17の市服の 高級ヤシガラ系活性洃の活性と同程度であることが知られた。 なお，同じよらに PVCゃ PC から乾式炭化・賦活により， つくった活性㷋は，表面皘 $S_{\mathrm{g}}$ が同程度であるにるかかからず， 本酸化反応系に対して，ほとんど触媒能を示さなかったことマと 対比すると, 含有金属成分の有無による相遟が，きわめて重要に なる。

本研究の遂行には，一部文部省科学研究費によった。 (1978 年 4 月, 化学工学協会第 43 年会(一部)発表)

26）茫川登，日化，1975，1217.

\section{Preparation of Activated Carbon from Various Species of Coal \\ -Effects of Direct Activation of Coal and That of Char Carbonized by Dry or Wet Method-}

Shigeaki Kasaoka, Yusaku Sakata, Makoto Umeno, Yoshiro ADACHI and Hitoshi Morishita

School of Engineering, Okayama University; Tsushima-naka, Okayama-shi 700 Japan

Preparation of activated carbon(AC) from 8 species of coal whose coking property and ratios $(1.8 \sim 7.7)$ of fixed carbon(FC) to volatile matter(VM) being differ widely, was studied to find the most suitable process or conditions to obtain a large surface area $S_{\mathrm{g}}\left(\mathrm{m}^{2}(\mathrm{AC}) / \mathrm{g}(\mathrm{AC})\right.$ ) and a high yield $Y\left(\mathrm{~g}(\mathrm{AC}) / \mathrm{g}\right.$ (raw coal)). The value of $S_{\mathrm{p}}=Y S_{\mathrm{g}}\left(\mathrm{m}^{2}(\mathrm{AC}) / \mathrm{g}\right.$ (raw coal)) or $S_{\mathrm{o}}=Y S_{\mathrm{g}} / \alpha\left(\mathrm{m}^{2}(\mathrm{AC}) / \mathrm{g}\right.$ (sum of FC and ash)) was used as a criterion, which was expected to attain a high value as possible.

The two-step activation process which was the combination of carbonization of coal to char 
with flowing air, $\mathrm{HCl}$-air mixture gas, $\mathrm{CO}_{2}$ (dry method), and/or conc. $\mathrm{H}_{2} \mathrm{SO}_{4}$ (wet method), and activation of char with steam, as well as other process of direct activation of coal were tried and compared, changing such experimental conditions as carbonization atmosphere, carbonization temperature and time $\left(4^{\circ} \mathrm{C} / \mathrm{min}, 300 \sim 400^{\circ} \mathrm{C}\right.$, mainly $3 \mathrm{hrs}$ for dry method; $150^{\circ} \mathrm{C}$, $1 \mathrm{hr}$ for wet method), activation atmosphere $\left(\mathrm{H}_{2} \mathrm{O}-\mathrm{N}_{2}, \mathrm{CO}_{2}, \mathrm{H}_{2} \mathrm{O}-\mathrm{CO}_{2}-\mathrm{N}_{2}\right.$; mainly $10 \% \mathrm{H}_{2} \mathrm{O}-$ $\mathrm{N}_{2}$ ), activation temperature, and time $\left(700 \sim 1000^{\circ} \mathrm{C}\right.$, mainly $\left.900^{\circ} \mathrm{C} ; 0.5 \sim 7 \mathrm{hrs}\right)$. Drying at $110^{\circ} \mathrm{C}$ for $1 \mathrm{hr}$ in air was selected as the weight criterion of raw coal $(-12 /+24$ mesh, average diameter $1.0 \mathrm{~mm}$ ).

The main results obtained are as follows :

(1) The coking property and the ratio of $\mathrm{FC} / \mathrm{VM}$ of coal in the direct activation process and the carbonization methods in the two-step activation process, namely the physicochemical properties of coal and char, controlled the pore developing process $\left(S_{\mathrm{p}}\right.$ vs. $Y ; S_{\mathrm{o}}$ vs. $\left.Y / \alpha\right)$ through the activation. The basic carbon structure of $\mathrm{AC}$, found by $\mathrm{X}$-ray diffraction analysis, had been determined by the structure of coal or char prior to activation.

(2) To prepare AC of large $S_{\mathrm{g}}$ in high yield, the direct activation and two-step activation by dry carbonization were excellent for raw coal whose FC/VM was below 3 or the content of $\mathrm{FC}+$ Ash was below $75 \%$, and the two-step activation by wet carbonization was suitable for raw coal of high degree of coalification. The typical performance in this study was to prepare AC with $S_{\mathrm{g}}=500 \sim 1000 \mathrm{~m}^{2} / \mathrm{g}$, whose yield being $40 \sim 70 \%$, comparable to commercial ACs.

(3) Steam $\left(10 \% \mathrm{H}_{2} \mathrm{O}-\mathrm{N}_{2}\right)$ activation at relatively high temperature $\left(900^{\circ} \mathrm{C}\right)$ for $0.5 \sim 2 \mathrm{hrs}$ was preferable to a low temperature and long-time operation. Pretreatment of char with an inactive gas $\left(\mathrm{N}_{2}\right)$ at $900^{\circ} \mathrm{C}$ improved the yield of $\mathrm{AC}$ during activation, forming partially hard carbon in char.

(4) Adsorption capactity (q) of prepared $\mathrm{AC}$ for $\mathrm{I}_{2}, \mathrm{UO}_{2}{ }^{2+}$ and $\mathrm{PO}_{4}-$ in liquid phase was independent of raw coal and preparation methods, and showed proportionality toward $S_{\mathrm{g}}$ as follows : $q\left(\mathrm{mg}\left(\mathrm{I}_{2}\right) / \mathrm{g}(\mathrm{AC})\right)=1.20 S_{\mathrm{g}} \cdots(\mathrm{A}), \quad q(\mathrm{mg}(\mathrm{U}) / \mathrm{g}(\mathrm{AC}))=0.18 S_{\mathrm{g}} \cdots(\mathrm{B}) \quad$ or $\quad q\left(\mathrm{mg}\left(\mathrm{PO}_{4}{ }^{-3}\right) /\right.$ $\mathrm{g}(\mathrm{AC}))=0.012 S_{\mathrm{g}} \cdots(\mathrm{C})$.

(5) Catalytic activity of prepared ACs for air oxidation of $\mathrm{Fe}^{2+}$ in sulfuric acid solution was comparable to that of commercial AC prepared from coconut shell. As reported previously. the ACs prepared from poly (vinyl chloride) and polycarbonate gave the same adsorption abilities as shown in Eqs. (A) and (B), but only half in Eq. (C), and no catalytic activity toward air oxidation of $\mathrm{Fe}^{2+}$. 